\title{
Soil compaction caused by timber harvesting in central Appalachian hardwood forests
}

\author{
Mark W. Jones \\ West Virginia University
}

Follow this and additional works at: https://researchrepository.wvu.edu/etd

\section{Recommended Citation}

Jones, Mark W., "Soil compaction caused by timber harvesting in central Appalachian hardwood forests" (2003). Graduate Theses, Dissertations, and Problem Reports. 1323.

https://researchrepository.wvu.edu/etd/1323

This Thesis is protected by copyright and/or related rights. It has been brought to you by the The Research Repository @ WVU with permission from the rights-holder(s). You are free to use this Thesis in any way that is permitted by the copyright and related rights legislation that applies to your use. For other uses you must obtain permission from the rights-holder(s) directly, unless additional rights are indicated by a Creative Commons license in the record and/ or on the work itself. This Thesis has been accepted for inclusion in WVU Graduate Theses, Dissertations, and Problem Reports collection by an authorized administrator of The Research Repository @ WVU. For more information, please contact researchrepository@mail.wvu.edu. 


\title{
SOIL COMPACTION CAUSED BY TIMBER HARVESTING IN CENTRAL APPALACHIAN HARDWOOD FORESTS
}

\author{
By \\ Mark W. Jones \\ Thesis submitted to the Davis College of Agriculture, Forestry, and \\ Consumer Sciences \\ At West Virginia University \\ in partial fulfillment of the requirements \\ for the degree of \\ Master of Science \\ in \\ Forestry \\ Approved by \\ Dr. Jingxin Wang, Committee Chairperson \\ Dr. Joseph McNeel \\ Dr. Pamela Edwards
}

Wood Industries

Morgantown, West Virginia 


\section{Abstract \\ SOIL COMPACTION CAUSED BY TIMBER HARVESTING IN CENTRAL APPALACHIAN HARDWOOD FORESTS}

by Mark W. Jones

Two commonly used harvesting systems in central Appalachia were examined to determine the amount of soil compaction associated with each harvest type. A manual system of chainsaw and cable skidder, along with a mechanized system consisting of feller-buncher and grapple skidder were monitored in two central Appalachian hardwood forest sites. Examinations of soil bulk density $\left(\mathrm{lbs} / \mathrm{ft}^{3}\right)$ were made pre-harvest and post-harvest for each harvest unit. Observations were conducted along the skid roads in conjunction to distance from the landing. Sample points were also taken systematically through each harvest site. The physical condition was recorded using a nuclear density probe. Data were analyzed statistically to determine the effect of operational variables on soil impacts. Results indicate that timber harvesting does affect the soil compaction levels in the woods, as well as along skid roads. Soil compaction also varies by different soil moisture level and soil series.

Keywords: Soil compaction, logging, forest operations, Appalachian hardwood forest. 


\section{DEDICATION}

I dedicate this project to my parents. I thank them for their moral and

financial support, and their unconditional love. I just hope they are proud of my long and unorthodox journey to achieve my Master's degree. 


\section{ACKNOWLEDGMENTS}

I thank the Mead-Westvaco Corporation, especially on their support in this project. Other thanks go to Dr. Jingxin Wang, Dr. Joe McNeel, and Dr. Pam Edwards for their support and guidance throughout this project. More thanks goes to Eldon Plaugher, Crystal Bowles of Mead-Westvaco of Elkins, WV. Thanks goes to Vince Judy of Allegheny Wood Products, for his support to this project. Also thanks goes out to the logging contractors for giving students the time and opportunity for fun and safe data collection. More deserving thanks

goes to a good friend and colleague, Charlie Long, for his incalculable help throughout the data collection of this project. 


\section{TABLE OF CONTENTS}

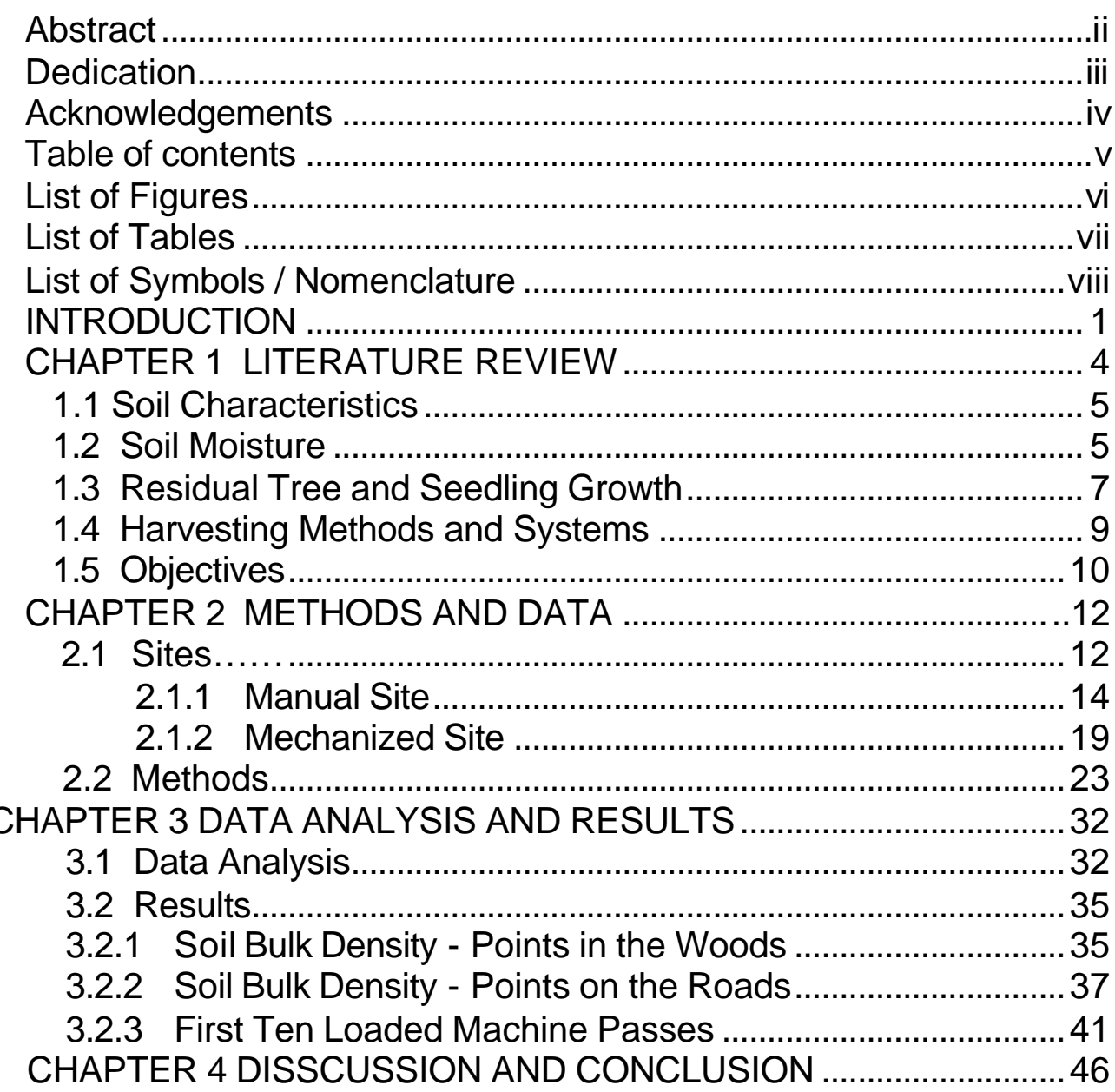

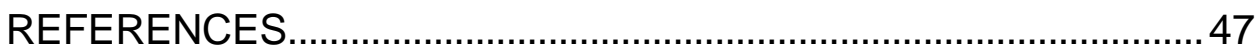




\section{LIST OF FIGURES}

Figure 2.1 Location Map for Harvest Sites ......................................13

Figure 2.2 Manual Harvest Site ....................................................17

Figure 2.3 Soil Map for Manual Harvest Site .................................18

Figure 2.4 Mechanized Harvest Site ...............................................21

Figure 2.5 Soil Map for Mechanized Harvest Site ..............................22

Figure 2.6 Manual Harvest Site Point Location ................................25

Figure 2.7 Mechanized Harvest Site Point Location..........................26

Figure 2.8 Example of sample points in the woods..........................27

Figure 2.9 Cross section of skid road layout ...................................28

Figure 2.10 Manual Harvest Site Road Point Layout ........................29

Figure 2.11 Mechanized Harvest Site Road Point Layout .................30

Figure 3.1 First ten loaded machine passes - Manual..................... 45

Figure 3.2 First ten loaded machine passes - Mechanized.............. 45 


\section{LIST OF TABLES}

Table 2.1 Site conditions..................................................................... 14

Table 2.2 Cruise data for manual harvest site.......................................... 15

Table 2.3 Manual harvest configuration ..................................................... 16

Table 2.4 Cruise data for mechanized harvest site.................................... 19

Table 2.5 Mechanized harvest configuration .......................................... 20

Table 3.1 Statistics of observed variables for points in the woods ..................... 36

Table 3.2 Means and significant levels of bulk density for point in the woods ...... 36

Table 3.3 Statistics for points in the roads .................................................. 38

Table 3.4 Means and significant levels of bulk density on roads ..................... 38

Table 3.5 Mean and significant of ten loaded machine passes ........................ 40 


\section{LIST OF SYMBOLS / NOMENCLATURE}

1. ac.................................Acre

2. AH..............................After Harvest

3. BF.............................Board Feet

4. bd.ft./ac..........................Board feet per acre

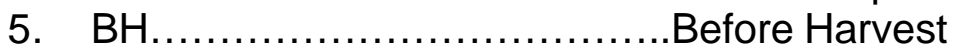

6. BMP ..............................

7. BtE...............................Bchanan and Ernest stony soils

8. DD................................Dry Density

9. DEP.............................. Division of Environmental Protection

10. GdE .............................. Gilpin-Dekalb stony complex

11. GkE .............................. Gilpin-Dekalb stony complex moist

12. GLM..............................General Linear Model

13. GPS .............................. Global Positioning System

14. LyC.............................. Lily loam

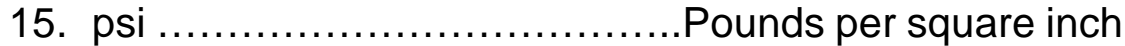

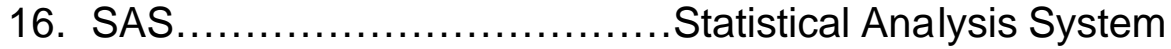

17. WD................................. Det Density 


\section{INTRODUCTION}

The forest floor is a continuing source of available plant nutrients, which contributes to the water-holding capacity of the soil, prevented erosion, and contained a bank of buried seeds vital for regeneration (Bormann and Likens 1979). Logging operations cause surface soil disturbance ranging from removal of the protective organic litter to complete removal of top-soil (Dyreness 1965). Any access or entry into a stand has the potential to disturb the forest floor and soil (Ogden and Morris 1996).

The use of forest roads and equipment has been increased due to selective harvesting of timber. Harvesting machines used for thinning sometimes cause residual stem and root damage with additional soil compaction, rutting, and nutrient relocation on the site $(\mathrm{McNeel}$ and Ballard 1992). Recent advances in harvesting techniques and product utilization have resulted in increasing occurrence of removing the entire aboveground biomass of trees. These methods are efficient, but require the use of heavy equipment, which may reduce site productivity by compacting the soil and/or disturbing the litter layer (Steinbrenner and Gassel 1955, Lull 1959, Froehlich 1979, Donnelly and Shane 1986). As extraction equipment has evolved from crawler-type tractors to wheel skidders and as felling machines have progressed from chain saws to mechanical harvesters, the percentage of disturbance has increased (Martin 1988). 
Regardless of the type of timber harvest or silvicultural treatment, logging always changes the site. These changes may include alterations of the litter layers, hydrology, erosion, growth rates, soils, and visual appearance.

Factors that influence soil disturbance and compaction include the amount and distribution of surface litter and slash, soil texture and structure, soil moisture, the weight and function of a machine, wheel size and slip, equipment speed, type of load, operator skill, topography, and weather (Burger 1983, Sirois et al. 1985). Trafficking, or the number of loaded machine is another major factor that can influence the soil compaction, over an area. Vehicular traffic associated with forest harvesting operations has the potential to compact and/or puddle forest soils (Hatchell et al. 1970, Aust et al. 1993).

The physical properties of the soil, texture and moisture have an effect on the level of soil disturbance. Soil compaction varies with soil texture and effects the operability of harvesting equipment. Erosion or sedimentation during and after logging also reflected in the type of harvest employed, because equipment greatly affects the amount of soil disturbance to the forest floor. Soil compaction affects the growth of seedlings and residual trees (Foil and Ralston, 1967), reduces the amount of air-filled pore space, and increases the proportion of micropores. The latter two factors decrease oxygen diffusion rates in soil, and increases soil moisture tension (Reisinger et. al. 1988).

During the past decade, forest harvesting methods available for the central Appalachian hardwood forests have evolved. Increased rates in worker's compensation, along with the demand for more production, have led to more 
mechanized harvesting systems throughout the central Appalachians. Soil changes caused from a mechanized system are unknown at this time due to the variability of soil types, site conditions, harvest types, harvest systems, and season of the year. While mechanized trafficking is believed to cause soil compaction or other effects to the soil the variability throughout the central Appalachian hardwood forest also makes the degree of change uncertain. Evaluations of the soil impacts among harvesting systems, silvicultural treatments, soil types, and soil conditions seem necessary in the region. 


\section{CHAPTER 1 LITERATURE REVIEW}

\subsection{Soil Characteristics}

Soil type can affect how soil is disturbed or compacted during a harvesting operation. Gent et al. (1984) reported a $17 \%$ increase in surface soil bulk density (from 1.16 to $1.36 \mathrm{Mg} / \mathrm{m}^{3}$ ) after whole-tree harvesting and a $36 \%$ increase (from 1.12 to $1.52 \mathrm{Mg} / \mathrm{m}^{3}$ ) on skid trails in a sandy clay loam with a moisture content of $27 \%$ at the time of harvesting. However, no increase in bulk density was observed on a sandy clay loam Piedmont soil at 15-cm depth following trafficking by a rubber-tired skidder or crawler (Burger et al. 1985).

Pote (2000) demonstrated that sandy soils in the inland zone show much less variability in the number of annual working days at the different probability levels. At least 233 predicted workdays were expected half the time on sandy soils, and at least 216 predicted workdays were expected in 9 out of 10 years. On loamy soils, the equivalent values for the inland zone were 183 days and 141 days, respectively. Pote (2000) also found that the clay soils in the coastal zone showed more variability in the number of workdays. In at least $50 \%$ of the years, 122 work days were expected, while in 9 out of 10 years ( $90 \%$ level), at least 7 workdays were anticipated. On sandy soils in that zone, the expected workdays were 252 and 225, respectively. Loamy soils had equivalent values of 172 and 108 days. 


\subsection{Soil Moisture}

Soil moisture is a major factor in controlling soil disturbance or compaction during a harvesting operation. Weaver and Jamison (1950) reported that compaction increased with moisture content throughout the moisture range of 6 12 percent in Davidson loam soil. Soil moisture at the time of trafficking also had a major influence on reduction and redistribution of pore space as soils were compacted (Seixas and McDonald 1997). Although a wide variety of site and machinery factors influence the soil disturbances, the likelihood of soil disturbance was enhanced on moist to saturated soils (Moehring and Rawls 1970, Greacen and Sands 1980, and Aust et al. 1995). Soils that are too wet to support heavy equipment would be compressed and rutted during harvesting, which could lead to increased bulk density, loss of soil macroporosity, increased erosion, decreased availability of water, and potential loss of productivity (Rachael and Karr 1989). Rutledge and McHardy (1968) reported that the soil was not tractable when soil moisture was near or above field capacity. Their study indicated a record high value of soil bulk density in an area that was harvested under conditions of relatively high soil moisture, as necessitated by the time constraints of the salvage effort. Conditions such as high moisture content above satisfactory levels would result in significant damage to the soil structure. Volumetric water contents increased as the level of disturbance increased (Aust et al. 1993). Rutting of the soils is a visual and physical impact and is common while harvesting timber, especially in wet or moist conditions. 
The impacts of harvesting under wet site conditions on soil physical properties and residual tree growth were examined in natural loblolly pine stands (Reisinger et al. 1994). They found that shallow rutting of corridors when soil conditions are wet is not necessarily detrimental to overall site productivity in spite of the visual impressions immediately after harvesting. Thinning operations should be planned when soil conditions are dry so as to minimize rutting, but if thinning must be done under wet conditions, the operations should be stopped when machine traffic creates deep ruts (Reisinger et al. 1994). The severity of soil disturbance from mechanized timber harvesting seems to be strongly related to soil wetness and drainage class. There is some evidence that soils in poorer drainage classes might be more severely disturbed during spring, summer, or autumn harvesting when soil is not frozen (Case and Donnelly 1979, Hatchell et al. 1970). The amount of undisturbed and severely disturbed soil on the harvested site differed among drainage classes (Turcotte et. al. 1991). There was less undisturbed soil on poorly drained than on moderately well drained soil; somewhat poorly drained soils had intermediate amounts of soil disturbance. There were more mineral ruts with severe disturbance on somewhat poorly and poorly drained soil than on moderately well drained soil. Soil moisture differences among drainage classes during harvesting operations apparently affect the extent of soil disturbance on drier soils. However, during wet conditions some wheel-rutting could be expected on all soils (Turcotte et al. 1991). 
Dickerson (1976) reported that bulk densities of wheetrutted Coastal Plain soils were increased about $20 \%$ in northern Mississippi, ranging in texture from loamy sand to silty clay loam. Aeration porosity (the air-filled pore space at a tension of $60 \mathrm{~cm}$ of water) was reduced by $68 \%$ after seven passes with a rubber-tired machine skidding tree-length logs. He also found the soils between the ruts that were compacted by the movement of logs had a $10 \%$ increase in bulk density and a $38 \%$ decrease in aeration porosity.

\subsection{Residual Tree and Seedling Growth}

Soil compaction affects the growth of trees and seedlings. Since partial cuts and thinnings are increasingly used, foresters have been concerning the effects of soil compaction on the growth of residual trees. Mechanized harvesting equipment commonly used for thinning southern pine stands might damage the soil and/or residual trees, thus negate the potential benefits of the thinning treatment (Reisinger et al. 1994). Soil nutrient availability was altered by changes to soil physical properties caused by the removal of forest floor and compaction during harvesting and site preparation (Hamlet et al. 1990, Briars et al.1995, Mo et al. 1995, Huang et al. 1996, Worrell and Hampton 1997). Soil compaction and loss of organic matter from the forest floor directly influences mineral weathering rates, nutrient mineralization and consequently plant growth (Zabowski et al. 1994, Worrell and Hampson 1997). The forest floor was very susceptible to disturbance by harvesting operations (Turcotte et al.1991). Mechanical disruption of the forest floor might have an adverse impact on site 
productivity because the forest floor is a major source of nutrients for shallow rooted spruce and fir seedlings (Hoyle 1965, Shaw et al. 1987). Growth of planted Douglas-fir seedlings on compacted tractor roads was significantly lower than seedlings in other cutover locations (Youngberg 1959). Several researchers have suggested that such disturbances might have long-term consequences for the management of pine plantations (Foil and Ralston 1967, Scheerer et al. 1995).

Some soil disturbances can be beneficial to seedling growth or regeneration. In two areas with naturally regenerated loblolly pine, secondary skid trails had an initial establishment of seedlings equal to, or greater than that on undisturbed soils, and shoot growth was less than that on undisturbed soil during the first two years (Hatchell et. al. 1970). Pine stocking during the first year was greater on secondary skid trails than on adjacent undisturbed soils, probably because skidding exposed the mineral soil. However, in one area, height growth on secondary trails was significantly less than that on disturbed soils. Reduced stocking and retarded height growth were also observed on primary skid trails, and detrimental effects were particularly severe on the finer textured soil. Seedlings in primary skid trails were less than half as tall as seedlings in undisturbed soil. Establishment and growth of pines were hampered to an even greater extent on log decks, which were more severely compacted and puddled than the primary skid trails. 


\subsection{Harvesting Methods and Systems}

All harvesting operations cause some compaction, but the degree of compaction varies with harvesting equipment, techniques, and intensity, and soil properties, especially moisture content and texture (Reisinger et. al. 1988).

Silvicultural treatments coupled with harvesting technique have an influence on how an area is disturbed and the severity. Soil disturbance averaged $17 \%$ in selection cuts and $28 \%$ in strip and patch clearcuts of northern hardwoods (Nyland et al. 1977). Dickerson (1968) reported that $21 \%$ of the soil in a clearcut stand was disturbed compared to $14 \%$ for an area with selective cut. He also found twice as much severely disturbed soil (barred, rutted, and compacted) on the clearcut site as on selective site. Willis (1971) found a similar result in a clearcut in Georgia. Approximately 5 to 10 percent of these areas, usually composed of log decks and primary skid trails, were considered seriously compacted. Hatchell et al. (1970) surveyed nine tractor skidder logged areas in South Carolina and Virginia and reported that $34 \%$ of the area was disturbed and $14 \%$ of the $34 \%$ (primary skid trails and log decks) classified as compacted.

Many studies compared the area disturbed by conventional logging with a tractor or skidder to a skyline system. Garrison and Rummell (1951) found mineral soil was exposed about $20.9 \%$ in tractor-logged areas, $15.2 \%$ of the total area where cables were used, and $11.8 \%$ in horse-logged areas in eastern Oregon and Washington. Steinbrenner and Gessel (1955) also studied tractor logged areas in 
western Washington and found $26 \%$ of the total area occupied by tractor skid roads. Wooldridge (1960) observed $29.4 \%$ of the ground surface was disturbed in a tractor logged area while only $11.1 \%$ was disturbed in the skyline area. Dyrness (1965) found a tractor-logged unit had about three times more area in the compacted disturbance class than did a high lead unit. Kochenderfer (1977) reported roads and landings accounted for $10.3 \%$ of skidder-logged area, and $7.8 \%$ for jammer-logged areas. McMinn (1984) found that a small skyline yarding operation disturbed only $1 \%$ of the total area compared to $37 \%$ and $16 \%$ of disturbance in two skidded areas excluding landings. A similar study in Mississippi found that a cable yarding required $2 \%$ less area in landings than skidding, and yarding corridors occupied $12 \%$ less area than skid trails (Miller and Sirois 1986).

\subsection{Objectives}

There are several problems associated with ground-based skidding in the central Appalachian hardwood forests. The single most important step to avoiding unnecessary road construction is proper harvest and road planning. As road density and miles of road increase, ground disturbance increase. The introduction of the feller-buncher in this region has also influenced how loggers harvest timber. The feller-buncher has increased production and improved logger's safety, but effects on soils may have worsened. However, since the introduction of the fellerbuncher in the central Appalachians, no studies have been conducted on the 
machine's effects on soil compaction, nor have feller-buncher effects been compared to other commonly used harvesting systems from perspectives of soil compaction and or soil disturbance. Therefore, the objectives of this study are to:

(1) Examine if the occurrence of soil compaction is significantly different between two commonly-used ground-based harvest systems in central Appalachian hardwood forests,

(2) Physically examine the amount of soil compaction on the skid roads and across the site by soil type, soil moisture, site condition, and harvest system, and

(3) Statistically analyze the amount of soil compaction associated with the harvest system, soil type/moisture, and site conditions. 


\section{CHAPTER 2 METHODS AND DATA}

\section{$\underline{2.1 \text { Sites }}$}

All harvest sites were located on Mead-Westvaco's forest in Randolph County, West Virginia (Figure 2.1). Harvesting plans in these areas were determined by Mead-Westvaco in context with their long-term forest management goals. The two study sites were similar in size and volume of wood removed per acre (Table 2.1). Average slope varied between the two harvested sites. The mechanized site was flatter with $5-20 \%$ slope, while the manual system was employed on relatively steeper slopes ranging from 30 to $40 \%$. 


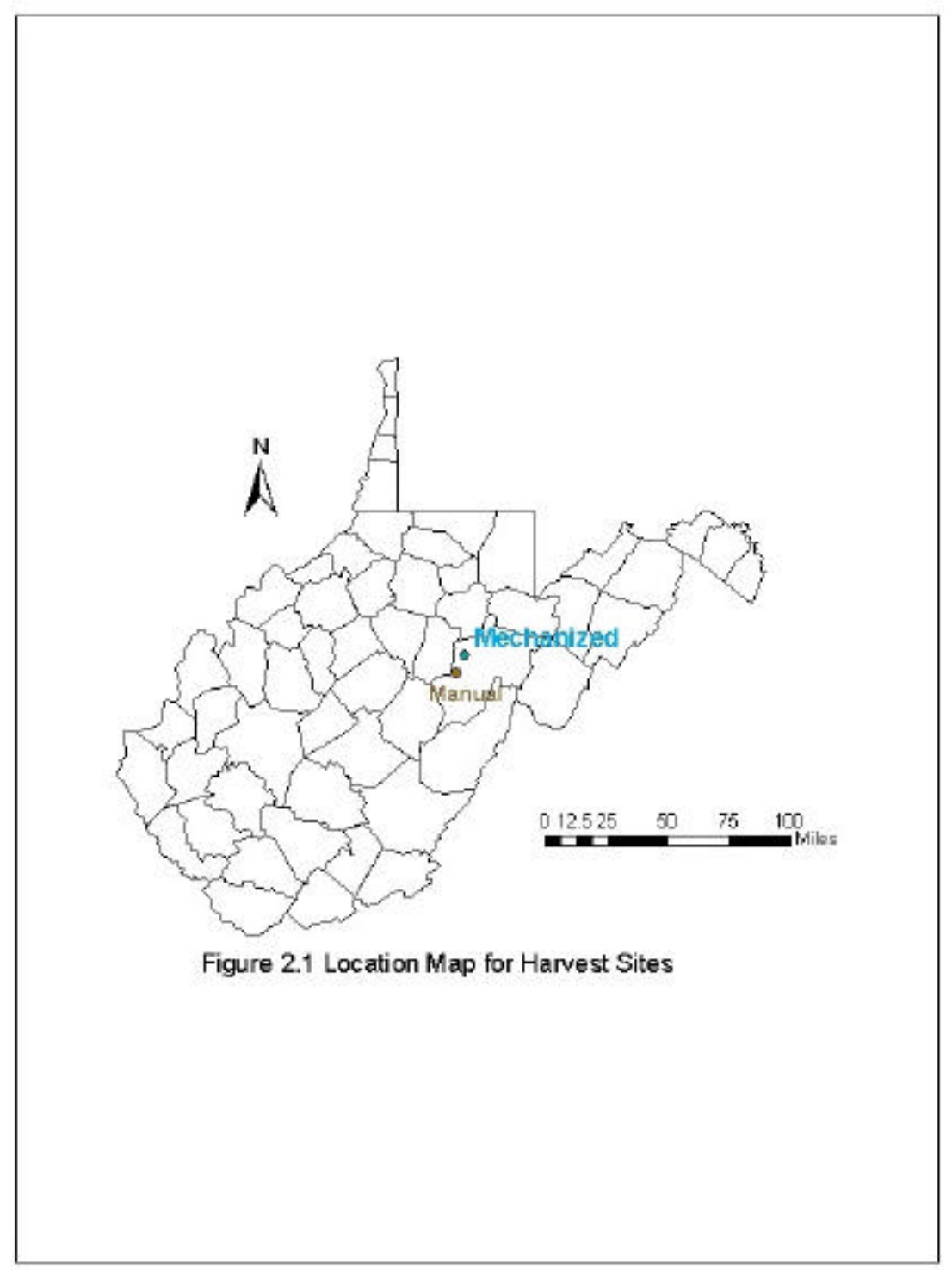


Table 2.1. Site conditions.

\begin{tabular}{lcc}
\hline \hline & Manual Site & Mechanized Site \\
\hline Harvest Method & Manual & Mechanized \\
Harvest Type & Selection & Clearcut \\
terrain slope $(\%)$ & $35-45$ & $15-25$ \\
aspect & Northeast & North \\
Time of Harvest & Summer & Summer \\
Tract Size (ac) & 31 & 34 \\
Volume (BF/ac) & 3,595 & 5,765 \\
Species Composition & Mixed Hardwoods & Mixed Hardwoods \\
\hline
\end{tabular}

\section{(1) Manual Site}

The manual harvesting site was located in the School Craft watershed, on the property of Mead-Westvaco. The tract was 31 acres in size. Tree volume removed was $3600 \mathrm{BF}$ per acre with the primary species including red oak (Quercus rubra), red maple (Acer rubrum), black birch (Betula nigra), chestnut oak (Quercus prinus), and basswood (Tilia Americana) (Table 2.2). The study area with north-facing slope was moderately steep (approximately 30 to 40 percent). Some scattered places in this tract were with $\geq 50 \%$ slope. The elevation ranges from $2600 \mathrm{ft}$. at the creek buffer to $3010 \mathrm{ft}$. at the ridge top (Figure 2.2).

Soils for the manual harvest site are primarily Gilpin series (GkE), though it is Buchanan (BtE) near the valley bottom. The Gilpin series is found on ridge 
tops, benches, side slopes, which consists of a well-drained and moderately deep soil. Slopes range from 3 to $70 \%$. Gilpin soils commonly are formed in acid material weathered from interbedded shale, siltstone, and sandstone. The Buchanan series is colluvial consisting of deep, moderately well drained, acidic soils. The Buchanan series is common on foot slopes, drainage ways, benches, and in coves. Slopes range from 3 to $35 \%$, but occur dominantly slopes from 15 to 35 percent (Pyle et al. 1967). Soil distribution in the manual harvest site is illustrated in Figure 2.3.

Table 2.2. Cruise data on the manual harvest site.

\begin{tabular}{lrrr}
\hline Species & $\begin{array}{r}\text { Volume } \\
\text { (BF/Acre) }\end{array}$ & $\begin{array}{r}\text { Total Volume } \\
\text { (BF) }\end{array}$ & $\begin{array}{r}\text { Percent } \\
\text { (\%) }\end{array}$ \\
\hline Black Cherry & 135 & 15,000 & 4 \\
Red Oak & 1189 & 132,000 & 33 \\
Black Walnut & 0 & 0 & 0 \\
Hard Maple & 189 & 21,000 & 5 \\
Soft Maple & 613 & 68,000 & 17 \\
Ash & 144 & 16,000 & 4 \\
Black Oak & 0 & 0 & 0 \\
White Oak & 18 & 2,000 & 1 \\
Poplar/Cuc & 243 & 27,000 & 7 \\
Scarlet Oak & 0 & 0 & 0 \\
Basswood & 270 & 30,000 & 8 \\
Chestnut Oak & 333 & 37,000 & 9 \\
Hickory & 27 & 3,000 & 1 \\
Black Birch & 342 & 38,000 & 10 \\
Beech & 36 & 4,000 & 1 \\
Black Locust & 9 & 1,000 & 0 \\
Y. Birch & 27 & 3,000 & 1 \\
Misc. Hdwd. & 18 & 2,000 & 1 \\
TOTAL & 3,595 & 399,000 & 100 \\
\hline
\end{tabular}

The manual harvesting system consisted of two timber fellers using chainsaws, one rubber-tired cable skidder, and one bulldozer. Table 2.3 illustrates the system configuration 
Table 2.3. Manual harvesting system configuration.

\begin{tabular}{lccc} 
Operation & Felling & Skidding & Other \\
Machine & Chainsaw & TJ 460D cable skidder & Case 650C dozer \\
No. of machines & 2 & 1 & 1 \\
\hline
\end{tabular}




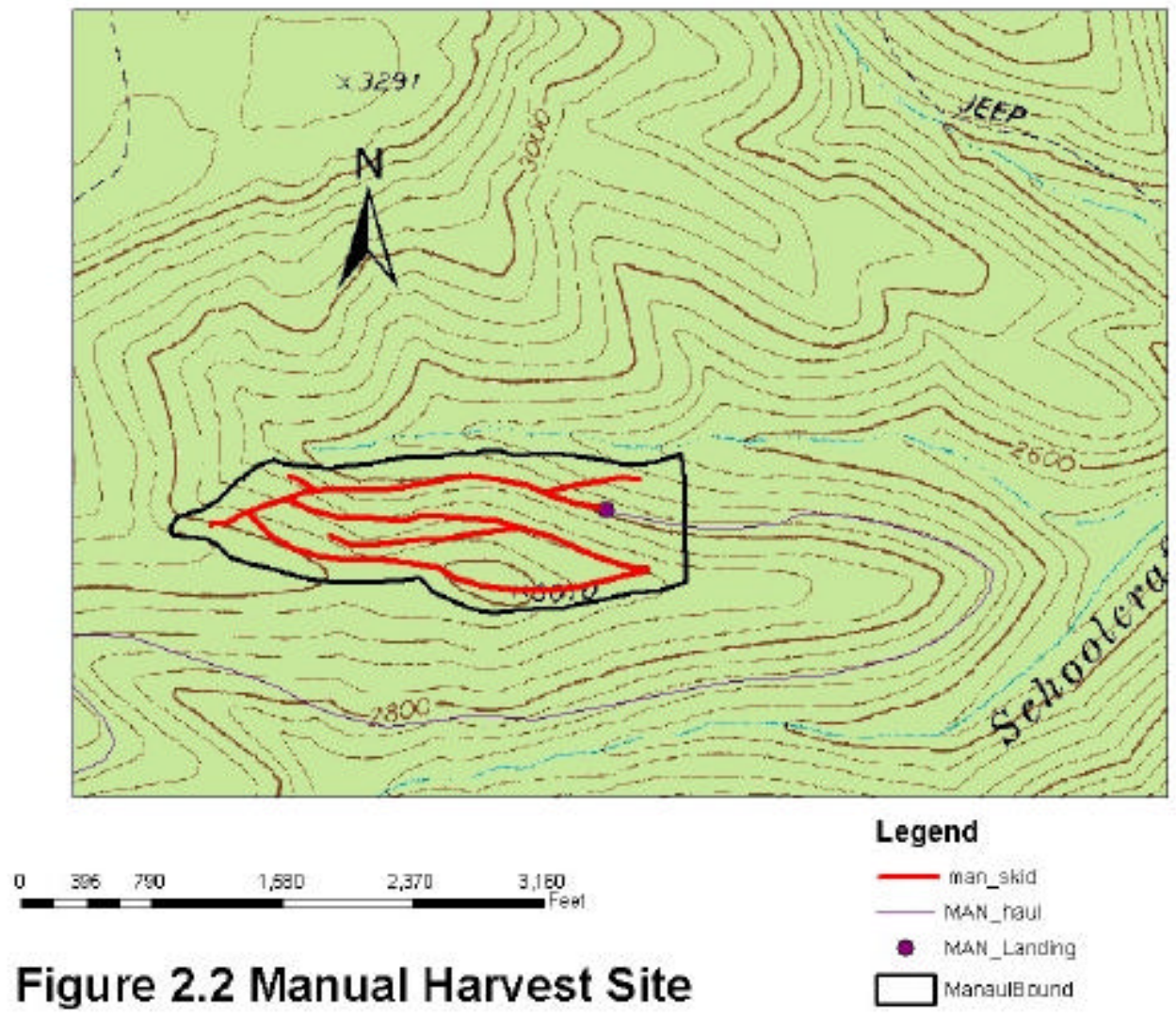




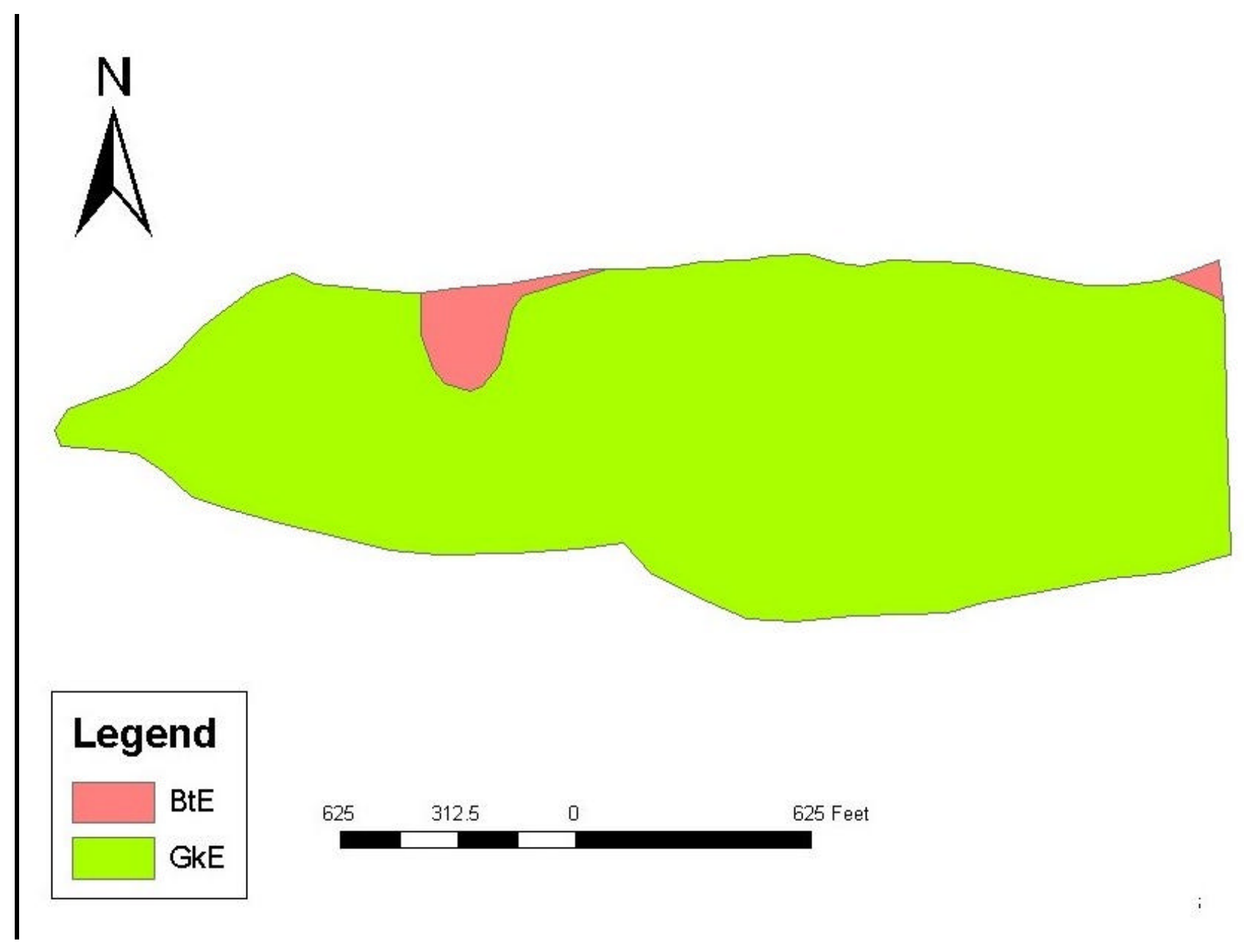

Figure 2.3 Soil Map for Manual Harvest Site 


\section{(2) Mechanized Site}

The mechanized harvesting site was located along Flatbush Fork, on the Mead-Westvaco property. The harvest area was 34 acres. Volume removed per acre was 5,765 BF, 196,000 BF in total. Primary species were poplar (Liriodendron tulipifera ), soft maple (Acer rubrum ), red oak (Quercus rubra), and chestnut oak (Quercus prinus)(Table 2.4).

Table 2.4. Cruise data for the mechanized harvest site.

\begin{tabular}{lrrr}
\hline Species & $\begin{array}{r}\text { Volume } \\
\text { (BF/Acre) }\end{array}$ & $\begin{array}{r}\text { Total volume } \\
\text { (BF) }\end{array}$ & $\begin{array}{r}\text { Percent } \\
(\%)\end{array}$ \\
\hline Black Cherry & 0 & 0 & 0 \\
Red Oak & 1265 & 43,000 & 22 \\
Black Walnut & 0 & 0 & 0 \\
Hard Maple & 29 & 1,000 & 1 \\
Soft Maple & 1353 & 46,000 & 23 \\
Ash & 147 & 5,000 & 3 \\
Black Oak & 0 & 0 & 0 \\
White Oak & 265 & 9,000 & 5 \\
Poplar/Cuc & 1559 & 53,000 & 27 \\
Scarlet Oak & 29 & 1000 & 1 \\
Basswood & 0 & 0 & 0 \\
Chestnut Oak & 676 & 23,000 & 12 \\
Hickory & 0 & 0 & 0 \\
Black Birch & 118 & 4,000 & 2 \\
Beech & 0 & 0 & 0 \\
Magnolia & 59 & 2,000 & 1 \\
Misc. Hdwd. & 265 & 9,000 & 5 \\
\hline
\end{tabular}

The mechanized site was north facing with approximately $10-20 \%$ of slope. Elevation ranged from $2440 \mathrm{ft}$ at the creek buffer to $2600 \mathrm{ft}$ at the southern boundary (Figure 2.4). Soils for the mechanized harvest site consists of Buchanan (BtE), Gilpin (GdE), and Lily (LyC) series. The Buchanan and Gilpin series were described earlier. The Lily series consists of deep, well-drained soils that formed 
from acid material weathered from sandstone and some interbedded siltstone and shale. The Lily soils exist primarily on ridge tops and benches. Slopes range from 3 to $15 \%$. Lily soils are on the landscape of well-drained Gilpin soils, and are less deep than Buchanan soils (Pyle et. al. 1967). The soil survey on the mechanized harvest site is illustrated in Figure 2.5.

Feller-buncher and grapple skidder were the two major machines in the mechanized system. The configuration of this system is listed in table 2.5.

Table 2.5. Mechanized harvesting system configuration.

\begin{tabular}{lccc}
\hline Operation & Felling & Skidding & Other \\
Machine & Timbco feller-buncher & JD 648IIG grapple \\
& skidder & - \\
No. of machines & 1 & 2 & - \\
& & & \\
\hline
\end{tabular}




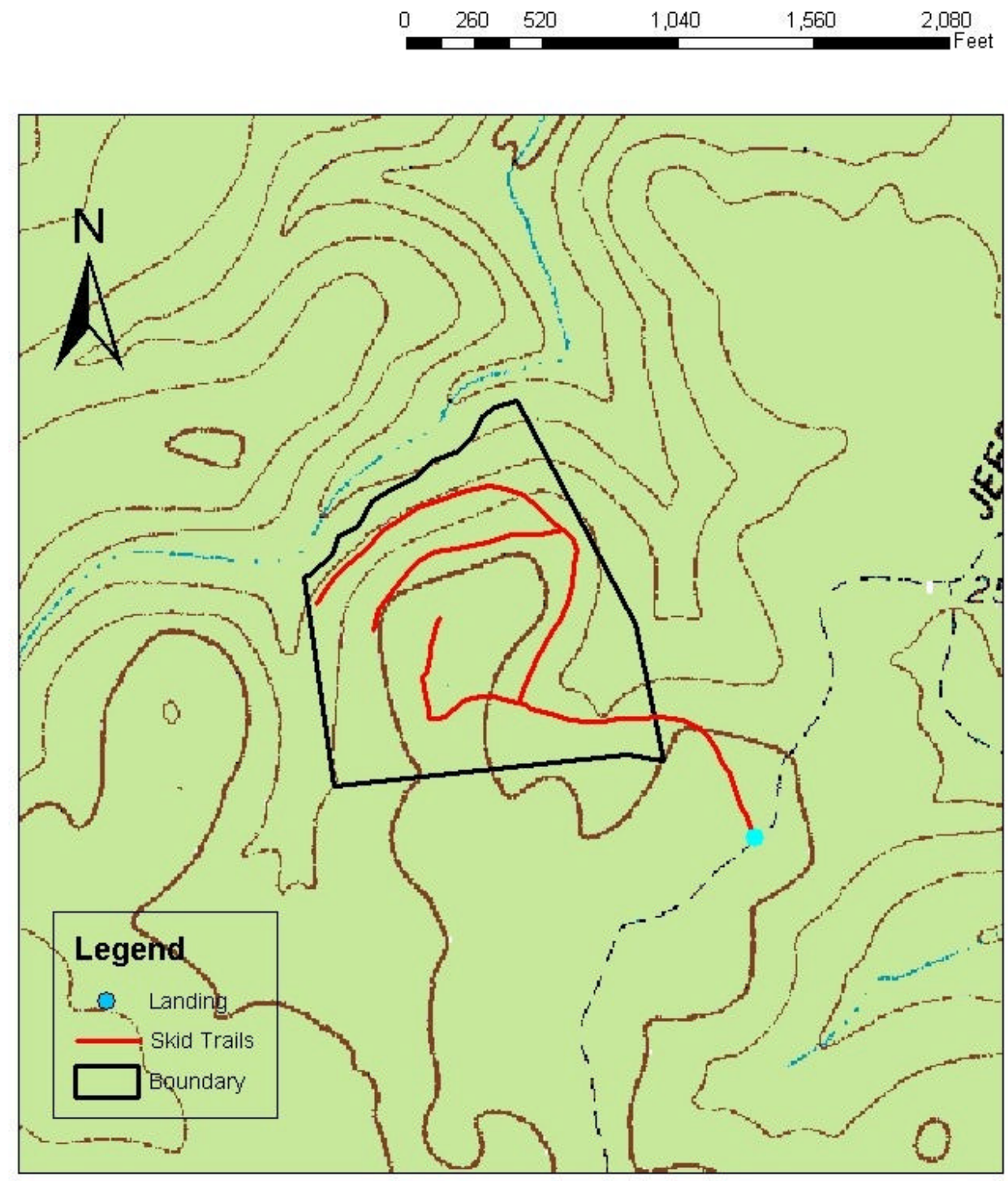

Figure 2.4 Mechanized Harvest Site 


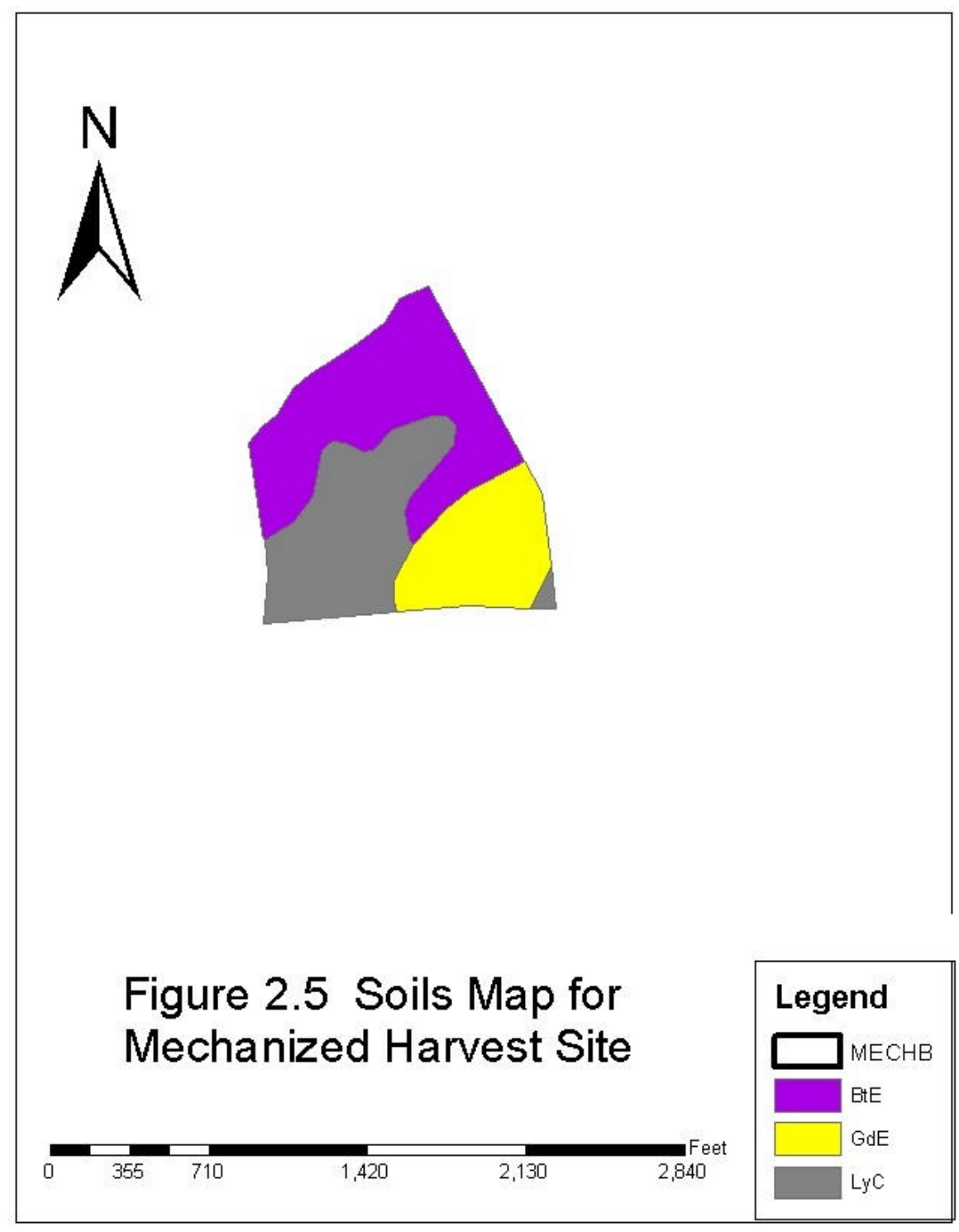




\subsection{Methods}

A completely randomized design (CRD) was employed for data collection in this study, which consisted of one block and two treatments. The block was defined as the timber harvest sites. Two harvesting sites were assumed similar in terms of stand and terrain conditions. The two treatments applied were manual harvesting system and mechanized harvesting system. Manual harvesting system employed chainsaw felling and a cable skidder while mechanized harvesting system consisted of a feller-buncher and grapple skidder. The mechanized system usually has no workers on the ground and makes it safer for the loggers.

Soil sample plots were pre-determined prior to harvest. Soil samples were taken on skid roads and throughout two harvested sites. Points were systematically located in the harvest sites, while the points on the skid roads were randomly placed. A GPS unit was used to map, record, and relocate the sample locations.

Thirty sampling locations were installed in each of two harvesting sites (Figure 2.6 and 2.7), which were systematically laid out using a grid of 3 by 3 chains. Four samples were taken at each location at random direction and distance (Figure 2.8). The core points taken across the site (not on the skid trails) were also recorded and mapped using the GPS unit. The direction was determined much like using your second hand on a wrist watch and the distance 
will be a random length up to 15 feet, which was determined using a program called "Randomizer" (www.randomizer.org) (Figure 2.8). 


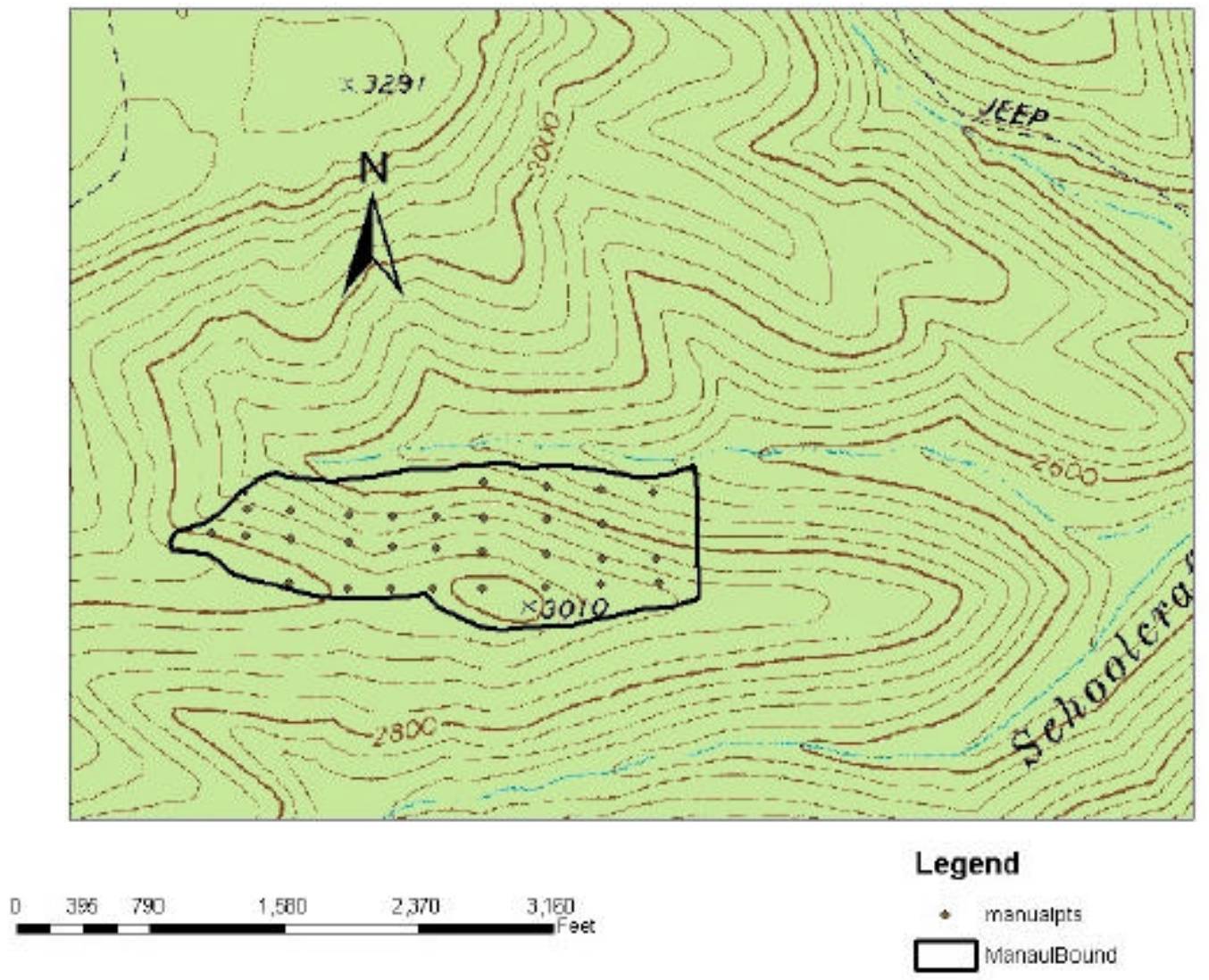

Figure 2.6 Manual Harvest Site Point Location 


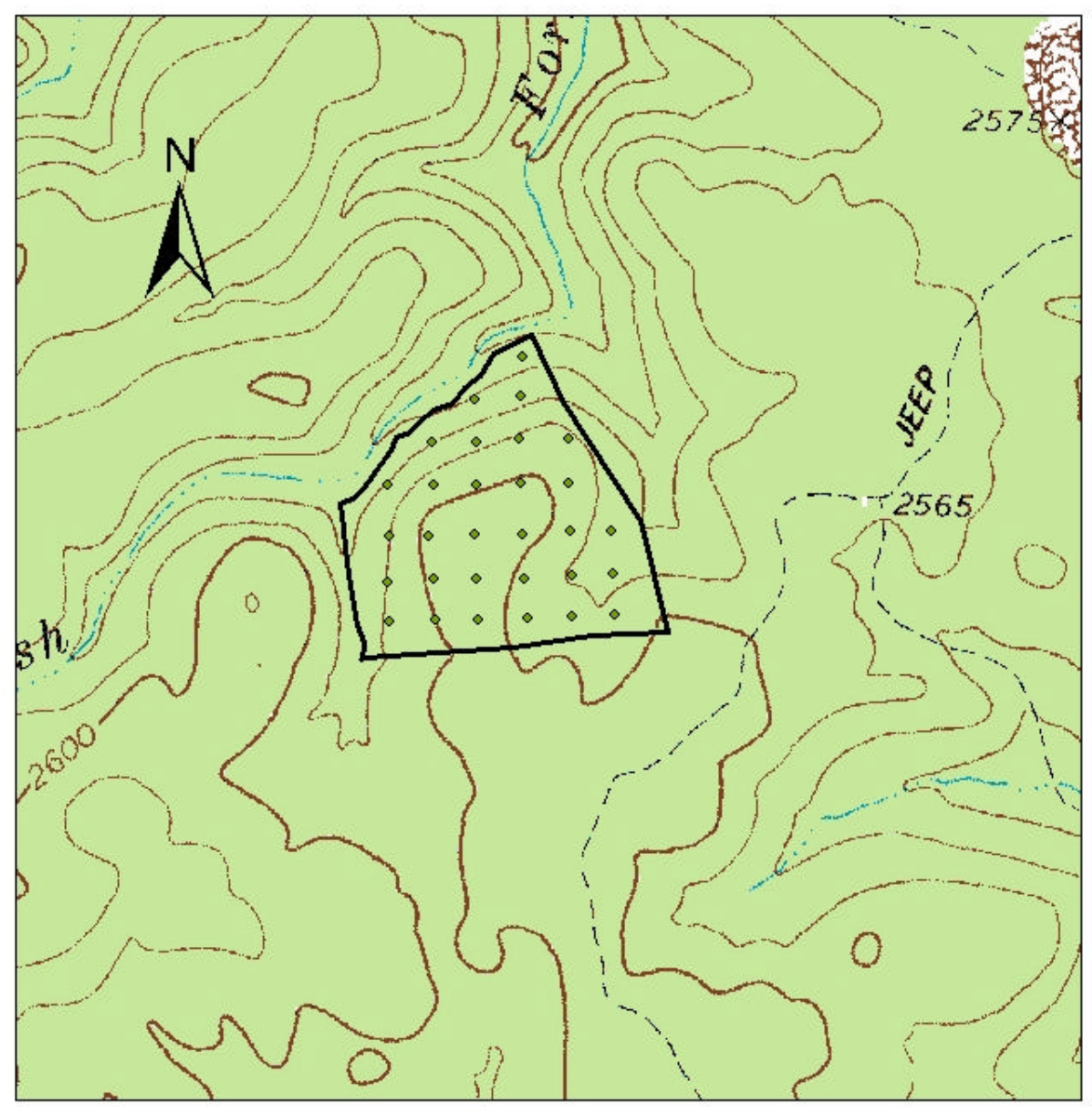

\section{Legend}

- MECH_pts

$\square$ Mech_Bound

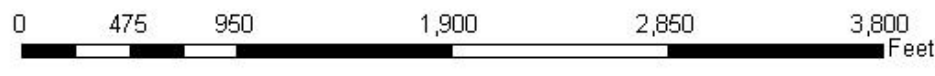

Figure 2.7 Mechanized Harvest Site Point Location 


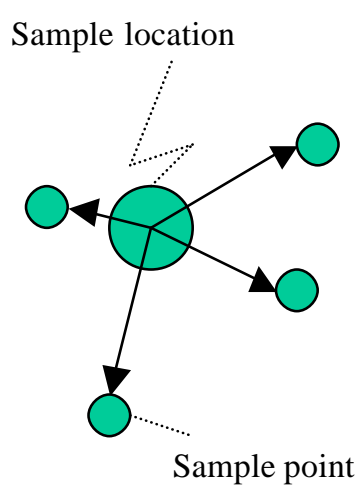

Figure 2.8 Example of sample points in the woods

Compaction on skid roads is directly related to the number of passes on the trail. Road closer to landing has more traffic, while it has considerably less traffic if the road is farther away from the landing. Consequently, the measurement locations were identified relative to the proximity of the landing. Six samples were taken at a cross section on the road (Figure 2.9). A total of 60 points were measured at 10 cross sections on the skid road in manual harvesting site (Figure 2.10) while 84 points were recorded at 14 cross sections on the road in mechanized site (Figure 2.11). 
points of measurements on skid trails

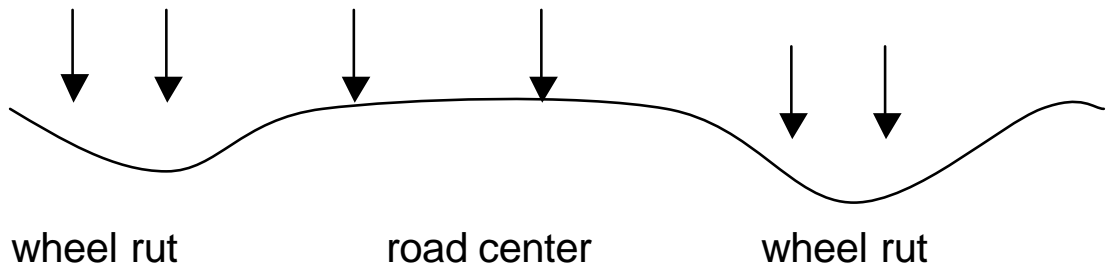

Figure 2.9 Cross section of skid road layout 


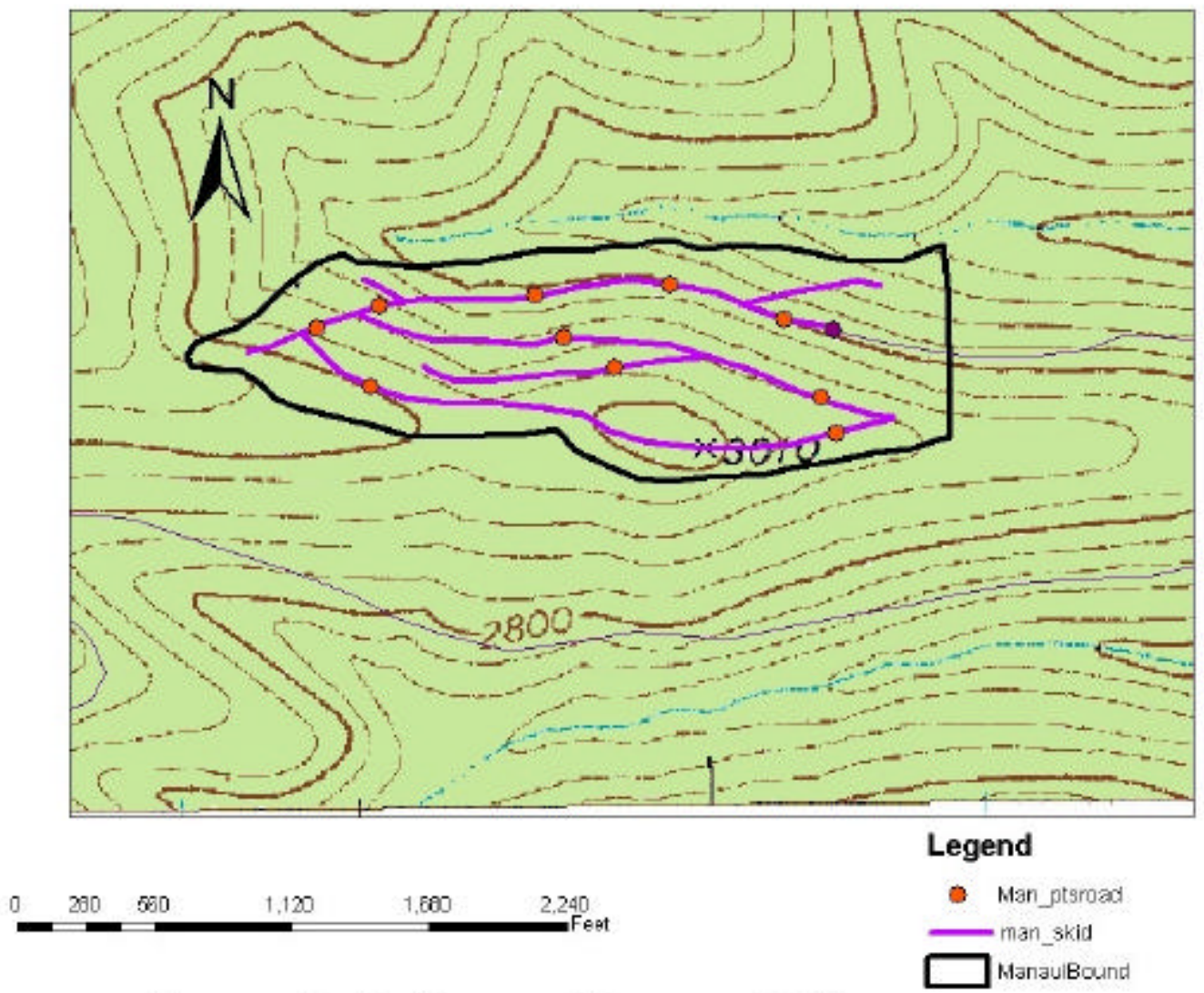

Figure 2.10 Manual Harvest Site Road Point Location 


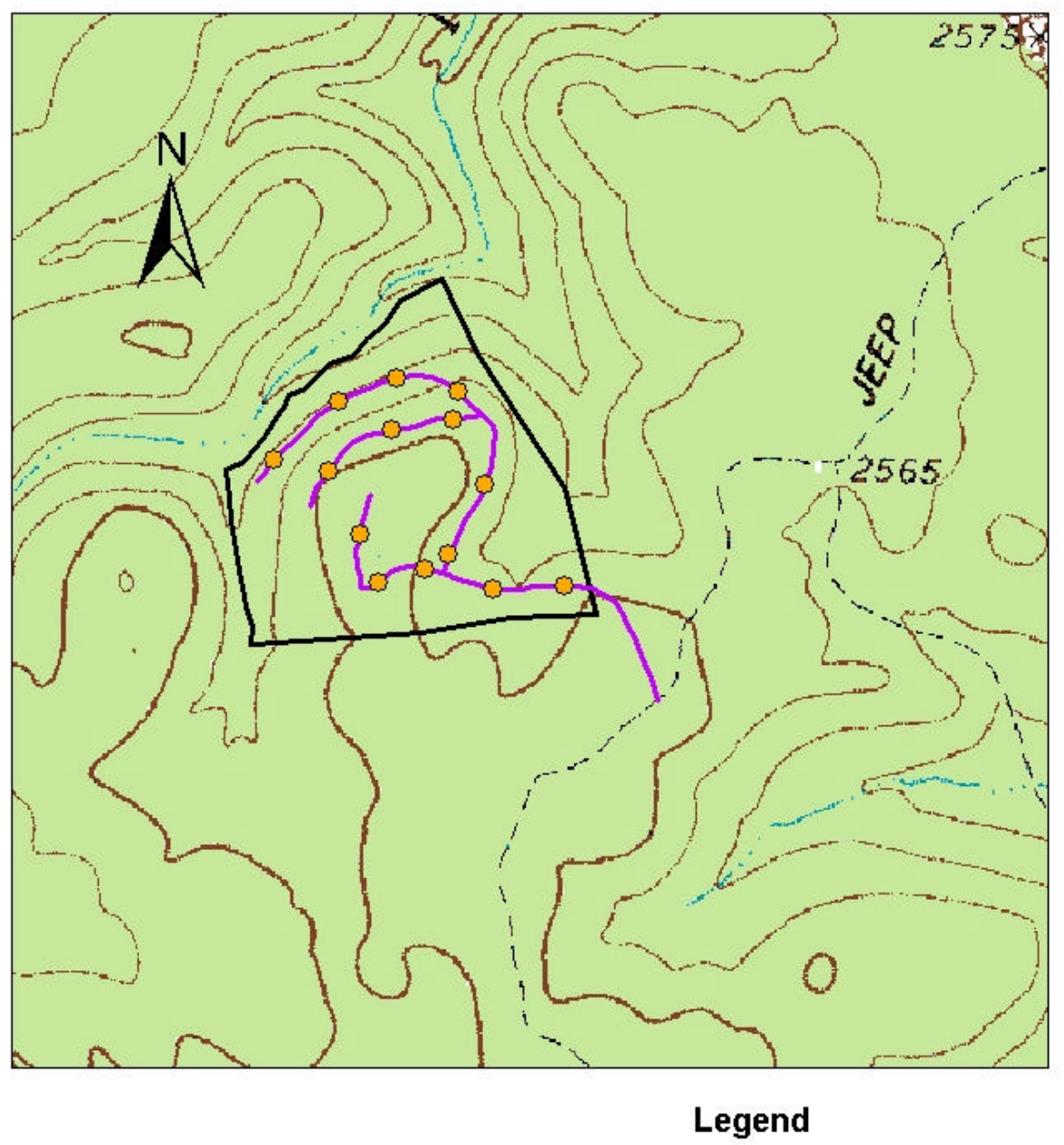

0 Mech_roadpts

$\longrightarrow$ Mech_Skid

ए Mech_Bound

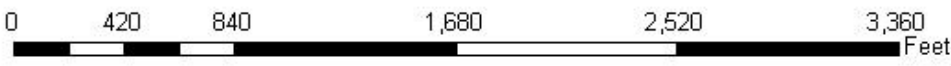

Figure 2.11 Mechanized Harvest Site Road Point Location 
The soil compaction associated with the first ten-loaded skidder passes were recorded at the first four cross section samples on the skid road in each site. The locations of the samples in relation to the log landing also were measured. Samples closer to a log landing generally have a greater number of loaded machine passes than those further away from the landing.

A Troxler density and moisture gauge was used to measure the soil density and soil moisture, which allows to take more samples and provide more accurate measurement. The Troxler can measure bulk density and soil moisture from 2 inches deep to 12 inches deep in increments of 2 in. Samples were measured six inches from the top of the surface to obtain soil bulk density in this study.

The independent variables measured were harvest type, harvest status (pre-harvest and post-harvest), soil types, and soil moisture. The quantitative measurements for the variables included wet density $\left(\mathrm{lb} / \mathrm{ft}^{3}\right)$, and dry density $\left(\mathrm{lb} / \mathrm{tt}^{3}\right)$. The wet density is the actual weight of the soil and water per unit volume. The dry density is the weight of the soil per unit volume. The soil compaction was computed by differentiating dry soil bulk densities after and before harvests.

Mean soil compaction was compared to determine if a difference between harvesting systems by harvesting status. The general linear model (GLM) was used to test if the significant differences of soil density or compaction exist among harvest system, harvest status, and soil moisture levels. Tests were performed using Duncan's multiple-range test at 0.05 level. 


\section{CHAPTER 3 DATA ANALYSIS AND RESULTS}

\subsection{Data Analysis}

Data were analyzed using Statistical Analysis Systems (SAS). A GLM model was performed to determine if any differences of soil bulk densities/compaction existed on three datasets: points in the woods, points in the roads, and first ten loaded machine passes.

(1) Points in the woods

The GLM model for soil bulk density for points in the woods is expressed

as:

$$
\begin{aligned}
& D_{i j k}=\mu+H S_{i}+H T_{j}+H S_{i}{ }^{*} H T_{j}+e_{i j k} \\
& i=1,2 \\
& j=1,2 \\
& k=1,2 \ldots n
\end{aligned}
$$

Where $D_{i j k}$ represents the $k^{\text {th }}$ observation of the soil bulk density (DD or WD); $\mu$ is the mean of each response variable; $H S_{i}$ is the effect of the ${ }_{i}$ th harvest system; $H T_{j}$ is the effect of the $\mathrm{j}$ th harvest status; $\mathrm{e}_{\mathrm{ijk}}$ is an error component that represents uncontrolled variability; and $n$ is the number of observations within each treatment. Interactions between harvest system and harvest status were also considered in the model. 
(2) Points in the road

This is the GLM model used for points on the roads:

$$
\begin{aligned}
& D_{i j k}=\mu+H S_{i}+H T_{j}+H S_{i}{ }^{*} H T_{j}+e_{i j k} \\
& i=1,2 \\
& j=1,2 \\
& k=1,2, \ldots n
\end{aligned}
$$

Where $D_{i j k}$ represents the $k^{\text {th }}$ observation of the soil bulk density (DD and WD); $\mu$ is the mean of each response variable; $\mathrm{HS}_{i}$ is the effect of the ${ }_{i}$ th harvest system; $\mathrm{HT}_{j}$ is the effect of the $\mathrm{j}$ th harvest status. Interactions between harvest system and harvest status were also considered in the model.

(3) Ten Loaded Machine Passes

A generic GLM for analyzing soil bulk densities associated with the first ten loaded machine passes is expressed as:

$$
\begin{aligned}
& D_{i j k l}=\mu+H S_{i}+N P_{j}+S M_{k}+H S_{i}{ }^{*} N P_{j}+H S_{i}{ }^{*} S M_{k}+N P_{j}{ }^{*} S M_{k}+e_{i j k l} \\
& i=1,2 \\
& j=1,2, \ldots .10 \\
& k=1,2 \ldots n
\end{aligned}
$$


Where $D_{i j k}$ represents the $k^{\text {th }}$ observation of the soil bulk density (DD and WD); $\mu$ is the mean of each response variable; $H S_{i}$ is the effect of the ${ }_{i}$ th harvest system; $N P_{j}$ is the effect of the th number of loaded machine passes; $S M_{k}$ is the effect of the ${ }_{k}$ th soil moisture; $e_{i j k l}$ is an error component that represents uncontrolled variability; and $n$ is the number of observations within each treatment. Interactions among harvest system, number of loaded machine passes and soil moisture were also considered in the model. 


\subsection{Results}

\subsubsection{Soil Bulk Density - Points in the Woods}

On the manual harvest site, the mean pre-harvest soil bulk densities were $65.75 \mathrm{lb} / \mathrm{ft}^{3} \mathrm{DD}$ and $84.44 \mathrm{lb} / \mathrm{ft}^{3} \mathrm{WD}$, respectively, while mean post-harvest soil bulk densities were $67.00 \mathrm{lb} / \mathrm{ft}^{3} \mathrm{DD}$ and $90.41 \mathrm{lb} / \mathrm{ft}^{3} \mathrm{WD}$. The mean bulk density showed an increase after the timber harvest was completed. An increased compaction level of $6.08 \mathrm{lb} / \mathrm{ft}^{3}$ was present on the manual harvest site (Table 3.1).

On the mechanized harvesting site mean pre-harvest soil bulk densities were $59.31 \mathrm{lb} / \mathrm{ft}^{3} \mathrm{DD}$ and $80.46 \mathrm{lb} / \mathrm{ft}^{3} \mathrm{WD}$, respectively. Mean post-harvest soil bulk densities were $59.48 \mathrm{lb} / \mathrm{ft}^{3} \mathrm{DD}$ and $77.62 \mathrm{lb} / \mathrm{ft}^{3} \mathrm{WD}$. The mechanized harvesting site showed an increased compaction level of $1.82 \mathrm{lb} / \mathrm{ft}^{3} \mathrm{DD}$ after harvest (Table 3.1).

Both DD $(F=40.20 ; d f=1,479 ; P=0.0001)$ and $W D(F=66.85 ; d f=1$, 479; $P=0.0001$ ) were significantly different between harvesting systems (Table 3.2). However, there was no significant difference for $D D(F=0.43$; $d f=1,479$; $\mathrm{P}=0.5147)$ and $\mathrm{WD}(\mathrm{F}=2.32 ; \mathrm{df}=1,479 ; \mathrm{P}=0.1283)$ between harvest statuses. Soil moisture did significantly affect the soil bulk density or compaction. Both DD and WD decreased as soil moisture level increased from $15 \%$ to $70 \%$. 
Table 3.1 Statistics of observed variables for points in the woods.

\begin{tabular}{|c|c|c|c|c|c|}
\hline Harvest status & Variable & Mean & Std. Dev. & Min. & Max. \\
\hline \multicolumn{6}{|c|}{ Manual harvesting system } \\
\hline \multirow{3}{*}{ Pre-harvest } & DD & 65.74 & 10.40 & 45.00 & 97.60 \\
\hline & WD & 84.44 & 8.71 & 64.10 & 110.70 \\
\hline & Smoist & 29.76 & 10.72 & 7.40 & 60.00 \\
\hline \multirow[t]{4}{*}{ Post-harvest } & DD & 67.00 & 13.91 & 39.80 & 114.00 \\
\hline & WD & 90.41 & 13.55 & 59.20 & 135.80 \\
\hline & Smoist & 36.74 & 11.34 & 12.80 & 72.80 \\
\hline & DD compaction & 6.08 & 8.97 & 0.00 & 42.40 \\
\hline \multicolumn{6}{|c|}{ Mechanized harvest system } \\
\hline \multirow[t]{3}{*}{ Pre-harvest } & DD & 59.31 & 12.05 & 32.30 & 97.40 \\
\hline & WD & 80.47 & 11.10 & 56.40 & 110.40 \\
\hline & Smoist & 36.74 & 11.34 & 12.80 & 72.80 \\
\hline \multirow[t]{4}{*}{ Post-harvest } & DD & 59.49 & 11.59 & 31.30 & 99.10 \\
\hline & WD & 77.62 & 11.05 & 50.60 & 108.20 \\
\hline & Smoist & 32.13 & 11.76 & 8.90 & 73.50 \\
\hline & DD compaction & 1.82 & 3.01 & 0.00 & 16.90 \\
\hline
\end{tabular}

Table 3.2. Means and significant levels of bulk density *

\begin{tabular}{rrr}
\hline \hline & Dry Density & Wet Density \\
\hline Harvest System & & \\
Manual & $66.37 \mathrm{~A}$ & $87.43 \mathrm{~A}$ \\
Mechanized & $59.40 \mathrm{~B}$ & $79.05 \mathrm{~B}$ \\
Harvest Status & & \\
Before Harvest & $62.53 \mathrm{~A}$ & $82.46 \mathrm{~A}$ \\
After Harvest & $63.24 \mathrm{~A}$ & $84.02 \mathrm{~A}$ \\
& & \\
Soil Moisture (\%) & & \\
$0-15$ & $83.52 \mathrm{~A}$ & $93.52 \mathrm{~A}$ \\
$16-30$ & $70.56 \mathrm{~B}$ & $87.27 \mathrm{~B}$ \\
$31-45$ & $59.89 \mathrm{C}$ & $81.92 \mathrm{C}$ \\
$46-60$ & $51.42 \mathrm{D}$ & $77.10 \mathrm{D}$ \\
$61-70$ & $41.72 \mathrm{E}$ & $69.59 \mathrm{E}$ \\
\hline${ }^{*}$ Means with the same letter are not significantly different at alpha $=0.05$ (ANOVA) &
\end{tabular}




\subsubsection{Soil Bulk Density - Points on the Roads}

Mean pre-harvest soil bulk densities on the roads in the manual site were $85.88 \mathrm{lb} / \mathrm{ft}^{3} \mathrm{DD}$ and $105.34 \mathrm{lb} / \mathrm{ft}^{3} \mathrm{WD}$. The mean bulk densities of DD and WD showed an increase after harvest. Mean post-harvest soil bulk densities were $93.16 \mathrm{lb} / \mathrm{ft}^{3} \mathrm{DD}$ and $112.21 \mathrm{lb} / \mathrm{ft}^{3} \mathrm{WD}$, showing an increased compaction level of $9.35 \mathrm{lb} / \mathrm{ft}^{3}$ on the manual harvesting site (Table 3.3).

On the mechanized harvesting site mean pre-harvest soil bulk densities were $81.88 \mathrm{lb} / \mathrm{ft}^{3} \mathrm{DD}$ and $98.73 \mathrm{lb} / \mathrm{ft}^{3} \mathrm{WD}$. Mean post-harvest soil bulk densities were $86.16 \mathrm{lb} / \mathrm{ft}^{3} \mathrm{DD}$ and $103.88 \mathrm{lb} / \mathrm{ft}^{3} \mathrm{WD}$, showing an increased compaction level of $7.88 \mathrm{lb} / \mathrm{ft}^{3}$ (Table 3.3).

For the points on the road, both $D D(F=15.39 ; d f=1,287 ; P=0.0001)$ and $\mathrm{WD}(\mathrm{F}=36.28 ; \mathrm{df}=1,287 ; \mathrm{P}=0.0001)$ were significantly different between harvesting systems (Table 3.4). Similarly, there was no significant differences of $D D(F=16.01 ; d f=1,287 ; P=0.0001)$ and $W D(F=23.00 ; d f=1,287 ; P$ $0.0001)$ between harvest statuses. The interaction between harvesting system and harvest status showed a significant effect on both $D D(F=1.14 ; \mathrm{df}=1,287$; $P=0.2874)$ and $W D(F=0.49 ; d f=1,287 ; P=0.4849)$. Soil moisture groups showed a trend that the lower the soil moisture the higher the soil bulk density. However, the higher the soil moisture the higher the soil compaction level. Soil moisture did significantly affect the compaction levels. 
Table 3.3. Statistics for points in the roads.

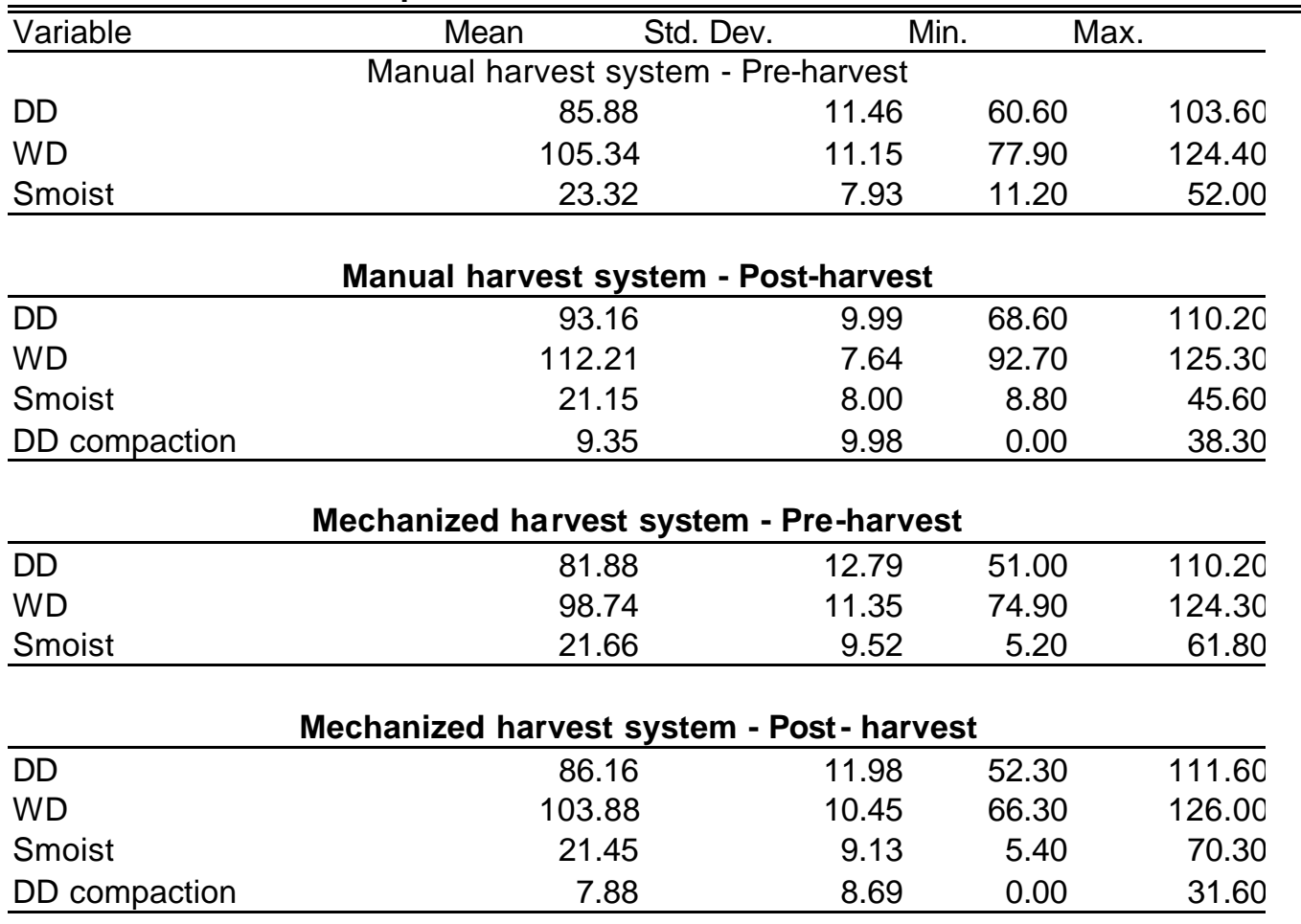

Table 3.4. Mean and significant levels of bulk density on roads*.

\begin{tabular}{ccc}
\hline \hline & Dry Density & Wet Density \\
\hline Marvest System & & \\
Manual & $89.52 \mathrm{~A}$ & $108.77 \mathrm{~A}$ \\
Mechanized & $84.02 \mathrm{~B}$ & $101.30 \mathrm{~B}$ \\
Harvest Status & & \\
Before Harvest & $83.55 \mathrm{~B}$ & $101.49 \mathrm{~B}$ \\
After Harvest & $89.08 \mathrm{~A}$ & $107.349 \mathrm{~A}$ \\
Soil Moisture Group & & \\
$0-15$ & $91.99 \mathrm{~A}$ & $109.61 \mathrm{~A}$ \\
$16-30$ & $89.60 \mathrm{~A}$ & $107.74 \mathrm{AB}$ \\
$31-45$ & $85.29 \mathrm{~A}$ & $107.38 \mathrm{AB}$ \\
$46-60$ & $75.40 \mathrm{AB}$ & $95.20 \mathrm{BC}$ \\
$61-70$ & $67.70 \mathrm{~B}$ & $92.53 \mathrm{C}$ \\
\hline
\end{tabular}




\subsubsection{First Ten Loaded Machine Passes}

The mean pre-harvest soil bulk density was $88.32 \mathrm{lb} / \mathrm{ft}^{3}$ on the manual harvesting site, which increased as the number of loaded machine passes increased (Figure 3.1). A decrease in soil compaction was shown after three or four passes. This might be attributed to the rutting observed after three or four loaded machine passes. As the soil was displaced, the bulk density decreased some. Then, as the soil displacement minimized, the bulk density increased as the number of loaded machine passes increased. The soil bulk density increased to $97.20 \mathrm{lb} / \mathrm{ft}^{3}$ after 10-loaded machine passes.

The soil bulk density on the mechanized harvesting site indicated a similar increasing trend as the number of loaded machine passes increased (Figure 3.2). However, as in the manual system a decrease in soil compaction was noticed as soil displacement occurred. A smaller decrease in soil density was recorded as rutting occurred. In addition, as the displacement minimized the bulk density increased as the number of loaded machine passes increased. An average bulk density of $78.22 \mathrm{lb} / \mathrm{ft}^{3}$ before harvest on the mechanized harvest site was observed and it increased to $88.75 \mathrm{lb} / \mathrm{ft}^{3}$ after five machine passes and $95.60 \mathrm{lb} / \mathrm{ft}^{3}$ after ten passes.

The DD for the first ten loaded machine passes showed a significant difference among machine passes $(F=4.01 ; d f=10,86 ; P=0.0007)$ (Figure 3.7). The DD $(F=29.51 ; d f=1,86 ; P=0.0001)$ was significantly different between harvest systems. Likewise, there was a significant difference for the DD $(F=$ $19.14 ; \mathrm{df}=4,86 ; \mathrm{P}=0.0001)$ among soil moisture groups. The interaction 
between harvest system and number of loaded machine passes did not significantly affect the $D D(F=0.81 ; d f=10,86 ; P=0.6164)$. No significant difference was identified in the interaction between the number of loaded machine passes and soil moisture groups $(F=0.30 ; d f=18,86 ; P=0.9958)$. Similarly, there was a significant difference for $D D(F=4.42 ; \mathrm{df} 2,86 ; \mathrm{P}=$ 0.0014) by the interaction between harvest system and soil moisture group.

Table 3.7. Means and significant levels of ten loaded machine passes.

\begin{tabular}{rrr}
\hline \hline & Dry Density & Wet density \\
\hline Harvest System & & \\
Mechanized & $89.52 \mathrm{~A}$ & $108.77 \mathrm{~A}$ \\
Soil Moisture Group & $84.02 \mathrm{~B}$ & $101.31 \mathrm{~B}$ \\
$0-15$ & $97.33 \mathrm{~A}$ & $117.98 \mathrm{~A}$ \\
$16-30$ & $95.94 \mathrm{~A}$ & $113.03 \mathrm{~A}$ \\
$31-45$ & $95.60 \mathrm{~A}$ & $112.17 \mathrm{~A}$ \\
$46-60$ & $93.49 \mathrm{AB}$ & $94.27 \mathrm{~B}$ \\
$61-70$ & $85.60 \mathrm{~B}$ & $89.50 \mathrm{~B}$ \\
Loaded Machine Passes & & \\
0 & $83.27 \mathrm{~B}$ & $103.60 \mathrm{~B}$ \\
1 & $90.30 \mathrm{~A}$ & $111.90 \mathrm{~A}$ \\
2 & $91.50 \mathrm{~A}$ & $112.91 \mathrm{~A}$ \\
3 & $91.67 \mathrm{~A}$ & $112.92 \mathrm{~A}$ \\
4 & $92.40 \mathrm{~A}$ & $113.15 \mathrm{~A}$ \\
5 & $93.09 \mathrm{~A}$ & $113.37 \mathrm{~A}$ \\
6 & $94.30 \mathrm{~A}$ & $113.71 \mathrm{~A}$ \\
7 & $94.77 \mathrm{~A}$ & $114.83 \mathrm{~A}$ \\
8 & $95.25 \mathrm{~A}$ & $115.00 \mathrm{~A}$ \\
9 & $95.81 \mathrm{~A}$ & $115.35 \mathrm{~A}$ \\
10 & $96.40 \mathrm{~A}$ & $116.44 \mathrm{~A}$ \\
\hline${ }^{*}$ Means with the same letter are not significantly different at alpha $=0.05$ (ANOVA)
\end{tabular}



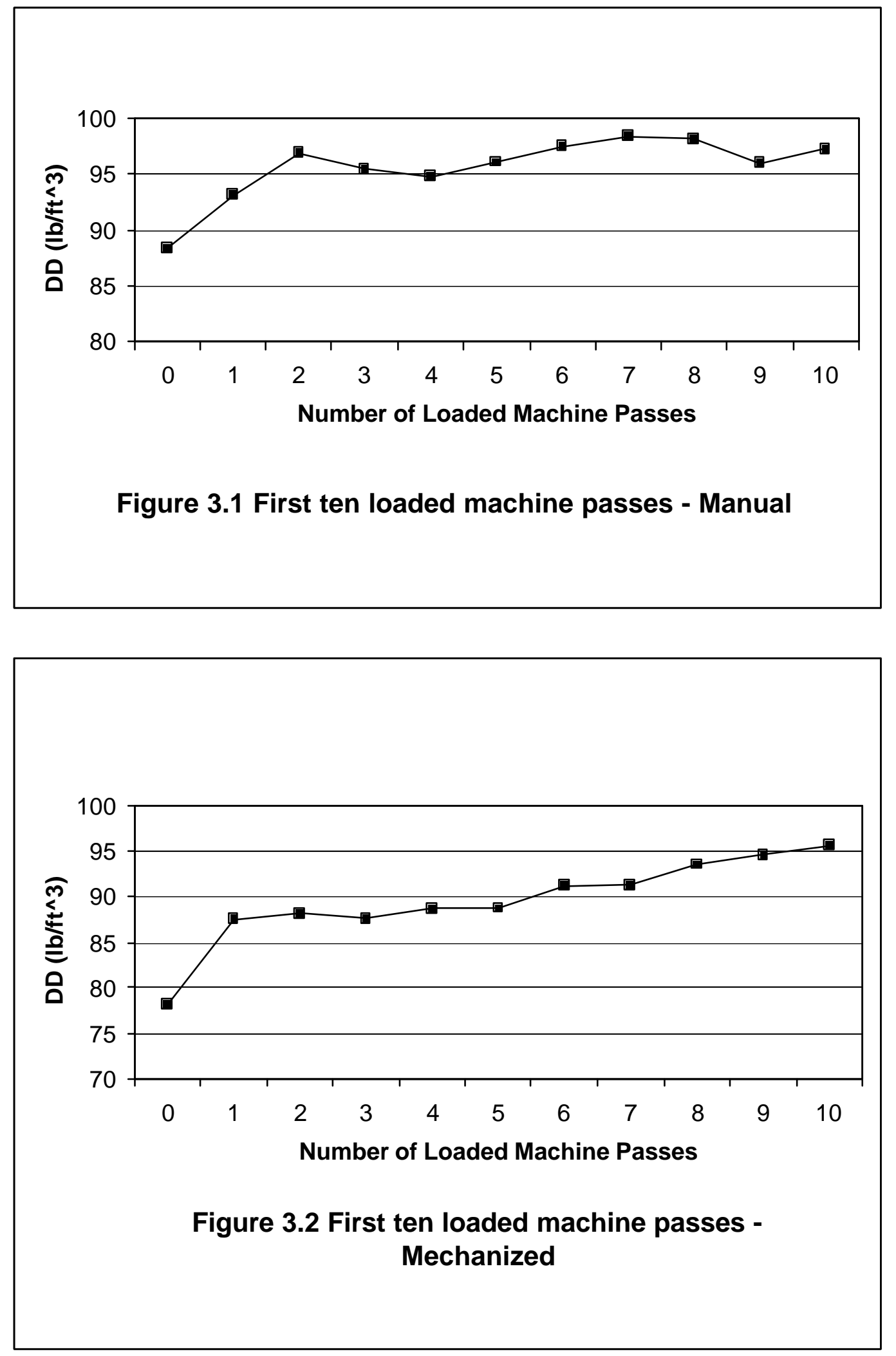


\section{CHAPTER 4 DISCUSSION AND CONCLUSIONS}

The manual harvesting system caused more soil compaction than the mechanized system. However, the compaction varied by soil types, harvest type, slope percent, operators experience and weather conditions. There are three reasons why the mean dry bulk density is lower on the mechanized harvest site than that on the manual harvest site. The manual harvesting operation started in the late spring and experienced approximately 6.5 inches of rainfall, while the mechanized system began in late July and finished in two weeks and had no rainfall. Secondly, the mechanized harvest site was preplanned and skid roads were put in two to three weeks prior to harvesting operations. There were no points in the woods that fell on the skid road system on the mechanized site. On the manual harvesting site, however, the skid roads were built as the operation progressed. Therefore, five locations for points in the woods were ultimately located on a skid road. Harvesting conditions such as the slope, can also contribute to this as well as preplanning or lack of planning. Finally, operator experience contributes to the amount of ground disturbance. The crew for the mechanized harvest system had no wasted motion. The feller-buncher bunched trees and the skidder got all the bunched trees in one turn. However, the cable skidder operator on the manual harvesting site sometimes skidded logs from the same point along the skid road three or four times before moving to another location. 
It would be interesting to compare the two systems in the same harvest type, harvest site and same time of the year. In addition, the comparison should be made for two ground-based systems with the same level of decision making by the loggers. There was a great deal of difference in the equipment and operators between the two harvesting systems, these factors might cause some compaction variability between the two systems.

The lower the soil moisture level the higher the mean bulk density. This is consistent with findings in previous studies. The soil moisture groups that made up of most of the samples were between 15 and 45 percent soil moisture. The mean bulk densities for these soil moisture groups are comparable on the two harvest sites.

Higher soil bulk densities were also observed on the skid roads in the manual harvesting site as compared with the densities on the skid roads in the mechanized site. The reasons are as follows: (1) the ground pressure for the TimberJack 460 cable skidder used in the manual site was 7.2 (psi), while the ground pressure for the John Deere 648GII grapple skidder in the mechanized site was 6.4 (psi); (2) the manual harvesting site had more precipitation during the harvest; and (3) the operator of the John Deere 648Gll cut tracks while skidding, on the mechanized site. This means the machine never ran in the same place twice. The skidder operator used the whole width of the road instead of traveling in the same wheel tracks.

The mean bulk density between the two harvest systems was significantly different between harvest statuses. This is expected when the roads were 
measured before any loaded machine passes versus the completion of the harvest. The bulk density on the roads gained approximately $7 \mathrm{lb} / \mathrm{ft}^{3}$ from before harvest to after harvest. Although this increase in density is significantly different, this is not a large amount of compaction.

The soil moisture in the road seems to have an inverse effect on soil compaction. Most of points were observed in the soil moisture levels of $0-15$ percent and 16-30 percent. These two soil moisture groups contained the highest mean bulk densities. All samples with soil moisture from 31 percent up to 70 percent seemed to have a lower soil bulk density. There were fewer points recorded in the higher soil moisture levels for the harvest systems on the skid roads and the higher soil moisture groups had the lower soil bulk density.

The bulk density on the manual harvesting site increased a $9.35-\mathrm{lb} / \mathrm{ft}^{3}$ from before harvest to after harvest, while the mechanized site experienced a 7.88 $\mathrm{lb} / \mathrm{ft}^{3}$ increase. Even though the tire size made a difference in ground pressure between the two systems the final compaction on the skid road was not significantly different between harvesting systems. It seems that the compaction on skid road does not directly relate to the harvesting system.

The higher the soil moisture the more likely the soil is to be compacted. Although, the lower soil moisture groups have a higher mean bulk density, the lower soil moisture resulted in the lower compaction. The soil compaction was not significantly different among soil moisture groups. The soil moisture tends to be low after road construction. The moisture dried out after the road was established. The loggers running the manual harvest system built roads as the 
harvest progressed, therefore, the soil moisture was higher than in the pre-planned roads on the mechanized system. This might have contributed to a higher compaction level on the skid roads.

Both harvesting systems showed an increase in soil compaction with the number of loaded machine passes. A small decrease in soil compaction was recorded as rutting began to occur for both harvest systems. For both systems, the soil compaction increased as the rutting stopped. However, more samples might help to improve the accuracy of this observation.

The silvicultural treatments (selection cut and clearcut) showed a difference for compaction, especially for points measured in the woods. However, further study is needed to evaluate these two silvicultural treatments using the same harvesting system. A comparison of the two harvest systems and two silvicultural treatments may produce a different result. The most ironic finding for this study was that the mechanized system along with a clearcut did not have as much compaction as the manual system on a selection cut. This finding can give a new base line for future studies. A selection harvest with the mechanized may result in more compaction than a clearcut.

Soil compaction on the roads was not significantly different comparing harvest systems as was expected. However, road planning will reduce the roads by area can be beneficial to soil compaction in a forest stand. 
Future monitoring should also include evaluating the fate of compacted soil on the skid roads. Soil bulk density should be evaluated each year or even every six months to determine how long it takes the soil to return to its original bulk density. Compaction did occur on skid roads, however, trees have grown on old skid roads. It would be beneficial to continue to evaluate the soil density for productivity purposes.

Soil compaction on different soil types was monitored during this research. However, the differences in the soil types for each site made it impossible to compare. Similar harvest sites with the same soil types would be beneficial for determining soil compaction by soil types. The BtE soil type was found on both sites in this study and presented similar compaction level. It was noticed that the BtE soil was easily compacted than other types. The GkE, which was on the manual site, and the GdE, which was on the mechanized site, also showed similar results in compaction. 


\section{REFERENCES}

Aust, W.M., Reisinger, T.W., and Stokes, B.J., 1993. Soil physical and hydrological changes associated with logging a wet pine flat with wide-tired skidders. South. J. Appl. For. 17(1): 22-25.

Bormann, F. H., and Likens G. E., 1979. Pattern and process in a forested ecosystem. Springer-Verlag, Inc., New York.

Brais, S., Camire, C., and Pare, D., 1995. Impacts of whole-tree harvesting and winter windrowing on soil $\mathrm{pH}$ and base status of clayey sites of northwestern Quebec Can. J. For. Res. 25,997-1007.

Burger, J.A. 1983. Physical impacts of harvesting and site preparation on soil. Proc. Soc. AM. For., Appalachian section annual meeting. 9p.

Burger, J.A., et al. 1985. The effects of track and rubber-tired vehicles on soil compaction. Trans. ASAE 28:369-373.

Busse, M.D., Cochran, P.H., and Barret, J.W. 1996. Changes in ponderosa pine site productivity following removal of understory vegetation. Soil Sci. Soc. Am. J. 60. 1614-1621.

Case, A.B., and Donnelly, J.G. 1979. Type and extent of ground disturbance following skidder logging with rubber-tired skidders. J. Soil and Water Conserv. 28(5): 218-220.

Dickerson, B.P. 1976. Soil compaction after tree-length skidding in northern Mississippi. Soil Sci. Soc. Am. J. 40:965-966. 
Donnelly, J.R. and Shane, J.B. 1991. Harevesting causes only minor changes in physical properties of upland Vermont soils. . North. J. Appl. For. 8 (33-36).

Dyrness C. T. 1965. Soil surface condition following tractor and high-lead logging in the Oregon Cascades. Jour. Forestry April 1965.

Egan, A. F., and Rowe, J. P. 1997. Compliance with West Virginia Silvicultural Best Management Practices 1995-1996. WV DOF Tech. Rpt. 97-1 (6/97) pp. 19. Egan, A. F., Whipkey, R. D., and Rowe, J. P. 1998. Compliance with Forestry 15(4) p211.

Froehlich, H. A. 1979. Soil compaction from logging equipment: effects on the growth of young ponderosa pine. J. Soil Water Conserv. 34:276-278.

Foil, R.R. and Ralston C.W. 1967. The establishment and growth of loblolly pine seedlings on compacted soils. Soil Sci. Soc. Amer. Proc. 31: 565-568.

Garrison, G.A., and Rummell, R.S. 1951. First-year effects of logging on ponderosa pine forest range lands of Oregon and Washington. Jour. Forestry 49:708-713. Illus.

Gent, J.A. Et al. 1984. Impact of harvesting and site preparation on physical properties of Piedmont forest soils. Soil Sci. Soc. Am. J. 48:173-177.

Greacen, E.L., and Sands, R. 1980. Compaction of forest soils: a review. Aust. J. Soil Res. 18: 163-189.

Hamlett, J.M., Melvin, S.W., and Horton, R. 1990. Traffic and soil amendment effects on infiltration and compaction. Trans. ASAE 33, 821-826.

Hatchell, G. E., Ralston, C.W. , and Foil, R.R. 1970. Soil disturbance in logging: Effects on soil characteristics and growth of loblolly pine in the Atlantic Coastal Plain. J. For. 68:772-775. 
Hoyle, M.C. 1965. Growth of yellow birch in a pozol soil. USDA For. Serv. Res. Pap. NE-38. 14p.

Huang, J., Lacey, S.T., and Ryan, P.J. 1996. Impacts of forest harvesting on the hydraulic properties of surface soils. Soil Sci. 161, 79-86.

Kochenderfer, J. N. 1977. Area in skidroads, truck roads, and landings in the central Appalachians. J. For. 75:507-508.

Kochenderfer, J. N., and Wendall, G. W. 1980. Costs and environmental impacts of harvesting timber in Appalachian with a truck-mounted crane. USDA For. Serv. Res. Pap. NE-456.

Lull, H. W. 1959. Soil compaction on forest and range lands. USDA For. Serv. Misc. Publ. No. 768. 33p. March 18, 2001Morgantown, WV 26505

Martin, C. W. 1988. Soil disturbance by logging in New England-Review and management recommendations. North. J. Appl. For. 5:30-34.

Martin, C. W., and Hornbeck, J.W. 1994. Logging in New England need not cause sedimentation of streams. North. J. Appl. For. 11(1): 17-23.

McMinn, J.W. 1984. Soil disturbance in mountain stands from feulwood harvests with conventional ground systems and a cable miniyarder. Georgia For. Pap. No. 54 p. 7.

McNeel, J. F., and Ballard, T. M. 1992. Analysis of site stand impacts from thinning with a harvester-forwarder system. J. of Forest Engineering 4(1):23-29.

Miller, J.H., and Sirois, D.L. 1986. Soil disturbance by skyline yarding vs. Skidding in loamy hill forest. Soil Sci. Soc. Am J. 50:1579-1583.

Mo, J., Brown, S., and Lenart, M. 1995. Nutrient dynamics of a human-impacted pine forest in a MAB reserve of subtropical China. Biotropica 27, 290-304. 
Moehring, D.M., and Rawls, I.W. 1970. Detrimental effects of wet weather logging. J. For. 68: 166-167.

Nyland, R. D. et al. 1977. Effects of logging in Northern hardwood forests. TAPPI 60(6):58-61.

Ogden, L. and Morris, L. 1996. Danial B. Warnell School of Forest Resources. University of Georgia.

Phillips, M, Swift, L, and Blinn, C. Best Management Practices for Riparian Areas. Riparian Management in Forests of the Continental Eastern United States. 1999. Chapter 16 p273.

Pote, J. W. 2000. Effects of climate and soil type interactions on probable work days with harvest equipment in Mississippi and Alabama forests. South. J. Appl. For. 24(4):213-218.

Rachael, J.M., and Karr, B.L. 1989. Effects of current harvesting practices on the physical properties of a loessal soil in west-central Mississippi P. 527-532 in Proc. Of the $5^{\text {th }}$ Bienn. South. Silvic. Res. Conf., Miller, J.E. (ed.) Memphis, TN.

Reisinger, T. W., Powell, D. B., Aust, W. M., and Oderwald, R. G. 1994. A postharvest evaluation of a mechanized thinning operation in natural loblolly pine. South. J. Appl. For. 18(1):24-28.

Reisinger, T.W., Simmons, G.L. and Pope, P.E. 1988. The impact of timber harvesting on soil properties and seedling growth in the south. South J. Appl. For. 12(1):58-67.

Rutledge, P.L., and McHardy, F.V. 1968. The influence of the weather on field tractability in Aberta. Can. Agric. Eng.10(2):70-73. 
Scheerer, G.A. 1994. Mitigation of harvesting disturbances on forested wetland in the South Carolina - 2 year results. P.236-243 in Proc. Eighth Bienn. South. Silivic. Res. Conf., Boyd, M.(comp.). USDA Dfor. Serv. Gen. Tech. Rep. SRS-1. $633 p$.

Seixas, F., and McDonald, T. 1997. Soil compaction effects of forwarding and its relationship with 6- and 8- wheel drive machines. Forest Prod. J. 47(11/12): 46-52.

Shaw, C. G. III, Sidle, R.C., and Harrison, A. S. 1987. Evaluation of planting sites common to a southeast Alaska Clear-cut. III. Effects of microsite type and ectomycorrhizal inoculation on growth and survival of sitka spruce seedlings. Can. J. For. Res. 17:334-339.

Sirois, D. L., Stokes, B. J. , and Ashmore, C. 1985. Primary transport of wood on sensitive sites in the Southeast. P. 122-127 in Proc. 1985 Counc. For. Eng.

Steinbrenner, E. C., and Gessel, S. P. 1955. Effect of tractor logging on soil and regeneration in the Douglas-fir region of southwestern Washington. P. 77-80 in Soc. Am. For. Proc., Bethesda, MD.

Steinbrenner, E. C., and Gessel, S.P. 1955. The effect of tractor logging on physical properties of some forest soils in southwestern Washington. Soil Sci. Soc. Amer. Proc. 19:372-376.

Turcotte, D.E., Smith, C. T., and Federer, C. A. 1991. Soil disturbance following whole-tree harvesting in North-Central Maine ${ }^{1}$. North. J. Appl. For. 8(2):68-72.

Ward, K. 1996. Timbering in West Virginia. Charleston Gazette. Sept. 8-11.

Weaver, J.R. and Neilson, W.A. 2000. The influence of forest site on rate and extent of soil compaction and profile disturbance of skid trails during ground-based harvesting. Can. J. For. Res. 30: 1196-1205. 
West Virginia Division of Forestry. June 2001. "Best Management Practices for Controlling Soil Erosion and Sedimentation from Logging Operations in West Virginia"

Willis, J. R. 1971. A case study of the effects of articulated rubber-tired skidders on physical conditions in Greene County, Georgia. M. S. thesis, Univ. Georgia, Athens.

Wooldridge, D.D. 1960. Watershed Disturbance from tractor and skyline crane logging. Jour. Forestry 58:369-372.

Worrell, R. and Hampson, A. 1997. The influence of some forest operations on the sustainable management of forest soils review. Forestry 70, 61-85.

Youngberg, C.T. 1959. The influence of soil conditions following tractor logging on the growth of planted Douglas fir seedlings. Soil Sci. Soc. Am. Proc. 23: 76-78.

Zabowski, D., Java, B., Scherer, G., Everett, R.L., and Ottmar, R. 2000. Timber harvesting residue treatment: Part 1. responses of conifer seedlings, soils and microclimate. Forest Ecology and Management 126 (2000) 25-34. 